\title{
STRONTIUM AND CARBON ISOTOPE STRATIGRAPHY OF THE LLANDOVERY (EARLY SILURIAN): IMPLICATIONS FOR TECTONICS AND WEATHERING
}

\author{
A Thesis \\ Presented in Partial Fulfillment of the Requirements for \\ The Degree Master of Science in the \\ Graduate School of The Ohio State University
}

\author{
By \\ Jeremy C. Gouldey, B.A. \\ $* * * * *$ \\ The Ohio State University \\ 2008
}

Master's Examination Committee:

Dr. Matthew R. Saltzman, Advisor

Approved by

Dr. Kenneth A. Foland

Dr. W. Berry Lyons

Advisor

Geological Sciences Graduate Program 



\begin{abstract}
A high resolution $\mathrm{Sr}$ isotope data set is generated for the Llandovery Series from a thick, fossiliferous drill core in Estonia. Observed ${ }^{87} \mathrm{Sr} /{ }^{86} \mathrm{Sr}$ values are at a minimum in the early Llandovery Rhuddanian Stage $(\sim 0.7079$ to 0.7080$)$, and then trend to more radiogenic ratios in the beginning part of the late Llandovery Telychian Stage. An ${ }^{87} \mathrm{Sr} /{ }^{86} \mathrm{Sr}$ high near $\sim 0.7084$ is observed in the Telychian at the top of the studied section. The range of values is in general agreement with previous sample sets of brachiopods and conodonts recovered from localities in North America and Europe that record a rising trend in the ${ }^{87} \mathrm{Sr} /{ }^{86} \mathrm{Sr}$ ratio throughout the Llandovery from approximately 0.7080 to 0.7084 .

The major increase in the ${ }^{87} \mathrm{Sr} /{ }^{86} \mathrm{Sr}$ ratio during the late Llandovery may be due to increased riverine flux of radiogenic $\mathrm{Sr}$ into the oceans due to: 1) weathering of non-volcanic continental silicate rocks that were uplifted during early Silurian continent-continent collisions, and 2) weathering of exposed felsic volcanics in the Balto-Scandanavian region that formed during subduction of continental crust. The presence of felsic volcanic rocks is consistent with the occurrence of an unusually thick K-bentonite bed (Osmundsberg K-bentonite) representing a large-magnitude ash fall in the early Telychian. Furthermore, a
\end{abstract}


negative $\delta^{13} \mathrm{C}$ excursion in marine carbonate and organic matter is quasisynchronous with the increase in $\mathrm{Sr}$ at the level of resolution currently available. As atmospheric $\mathrm{CO}_{2}$ was apparently being drawn down in the preceding Aeronian Stage (positive $\delta^{13} \mathrm{C}$ excursion), the large amounts of ash may have been a catalyst for the ensuing Telychian glaciation, causing a major regression and further contributing to the increase in ${ }^{87} \mathrm{Sr} /{ }^{86} \mathrm{Sr}$ through increased continental weathering. 


\section{ACKNOWLEDGEMENTS}

I would like to give special thanks to my advisor Dr. Matthew Saltzman, for all his hard work and encouragement throughout this project. Without his guidance, assistance, and devotion, this project would not have been possible. I am very grateful for all the time he spent discussing this work with me and helping me to grow as a researcher. I am also very thankful towards my committee members, Dr. Berry Lyons and Dr. Kenneth Foland, for all their support and helpful comments.

The isotope data generated from this study would not have been possible without the help of several people. All the strontium isotope data was generated in Dr. Kenneth Foland's Radiogenic Isotope Lab at The Ohio State University, and without his assistance, and the invaluable assistance of his lab technician Jeff Linder, this data would not exist. All the carbon isotope data generated in this study was done in Dr. Andrea Grottoli's Stable Isotope Biogeochemistry Lab, and I am very grateful for her assistance, the invaluable assistance from her lab technician Yohei Matsui, and assistance with sample processing from graduate student Abbey Chrystal.

Sample collection would not have been possible without the help of some important people. Samples from Estonia were collected by graduate student Seth 
Young, under the permission of Dr. Dimitri Kaljo (Institute of Geology at Tallinn University of Technology). Field work in Nevada was possible thanks to the assistance of fellow graduate students Brad Cramer, Kate Tierney, Alyssa Bancroft, and Alexa Sedlacek, RIL lab assistant Tom Wood, and directions and unpublished data provided by Dr. Peter Sheehan (Milwaukee Public Museum).

I would also like to thank my fellow graduate students for their insight and the rest of the faculty who aided through their teaching and support during my time at Ohio State University. My family has always provided continuous support of my work, and without that I would be lost.

Funding for this project was provided by a grant from the Friends of Orton Hall fund, NSF grant EAR-0452220: Technician Support: Ohio State University, Radiogenic Isotopes Laboratory - Phase II, and graduate teaching and research assistantships. 


\section{VITA}

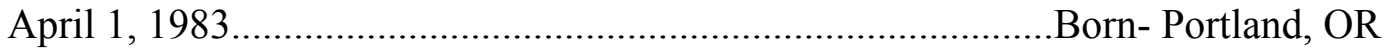

Summer, 2002-Fall, 2003 ..............................Research Assistant, Albion College

Winter, 2003-Spring, 2005...........................Teaching Assistant, Albion College

Summer, 2005...........................Hydrologist, USGS Water Resources of Indiana

Fall, 2005 .................................................... Geology, GIS, Albion College

Fall, 2006-Spring, 2007..Graduate Teaching Associate, The Ohio State University

Fall, 2007-present...........Graduate Research Associate, The Ohio State University

\section{FIELDS OF STUDY}

Major field: Geological Sciences

Studies in chemostratigraphy, stratigraphy, biostratigraphy, and isotope geochemistry 
TABLE OF CONTENTS

$\underline{\text { Page }}$

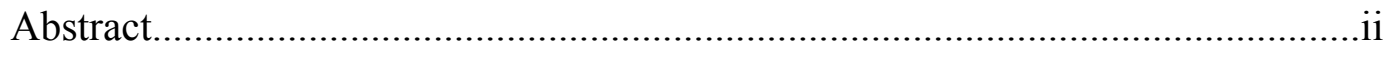

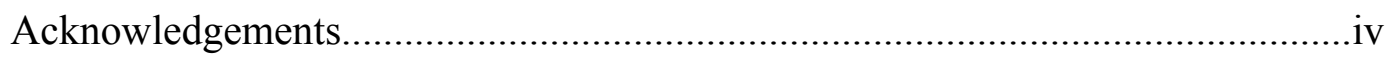

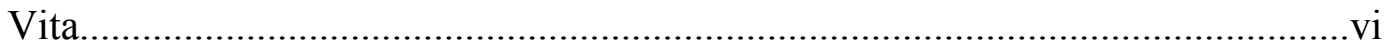

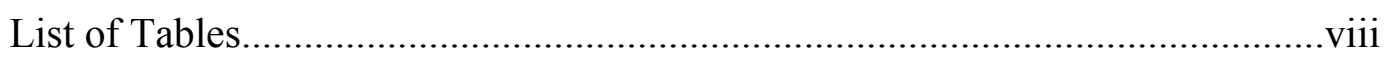

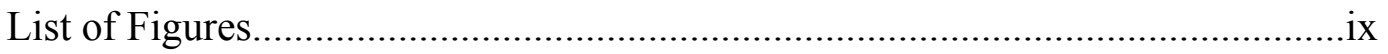

Chapters

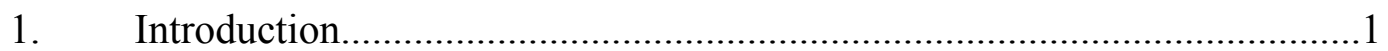

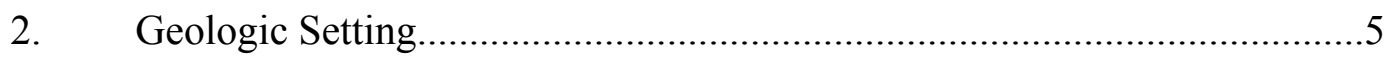



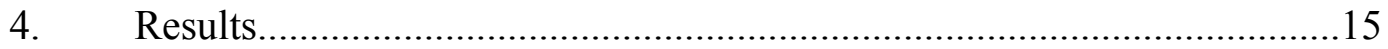

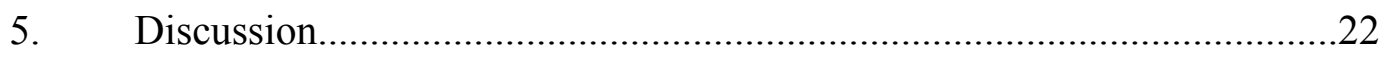

6. Relation to Climate, Sea Level, and Carbon Cycling.................................30

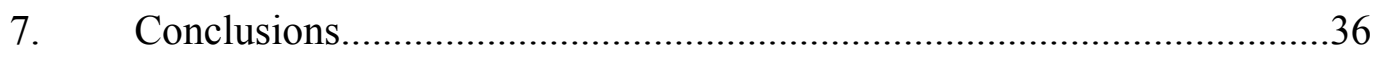

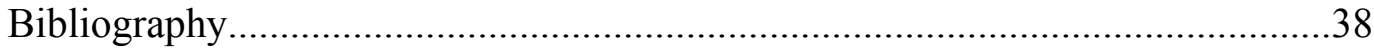

Appendices

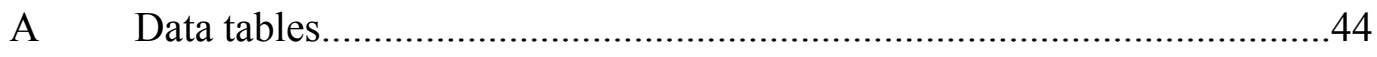

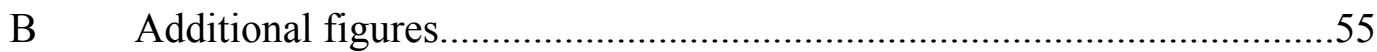

vii 


\section{LIST OF TABLES}

$\underline{\text { Table }}$

$\underline{\text { Page }}$

1 Stable isotope data from Ikla core. Uncertainites are two-sigma mean internal reproducibilities, typically based upon 100 measured ratios. The ${ }^{87} \mathrm{Sr} /{ }^{86} \mathrm{Sr}$ ratios given are normalized for instrumental fractionation using a normal ratio for ${ }^{86} \mathrm{Sr} /{ }^{88} \mathrm{Sr}$ of 0.119400 . The Laboratory reference value for the SRM 987 standard is $\left({ }^{87} \mathrm{Sr} /{ }^{86} \mathrm{Sr}\right)=0.710242$ \pm 0.000010 (one one-sigma external reproducibility). No modifications to the measured normalized ${ }^{87} \mathrm{Sr} /{ }^{86} \mathrm{Sr}$ ratios have been made

2 Stable isotope data from Pancake Range. Uncertainites are two-sigma mean internal reproducibilities, typically based upon 100 measured ratios. The ${ }^{87} \mathrm{Sr} /{ }^{86} \mathrm{Sr}$ ratios given are normalized for instrumental fractionation using a normal ratio for ${ }^{86} \mathrm{Sr} /{ }^{88} \mathrm{Sr}$ of 0.119400 . The Laboratory reference value for the SRM 987 standard is $\left({ }^{87} \mathrm{Sr} /{ }^{86} \mathrm{Sr}\right)=$ $0.710242 \pm 0.000010$ (one one-sigma external reproducibility). No modifications to the measured normalized ${ }^{87} \mathrm{Sr} /{ }^{86} \mathrm{Sr}$ ratios have been made 


\section{LIST OF FIGURES}

$\underline{\text { Figure }}$

$\underline{\text { Page }}$

1 Paleogeographic reconstruction of the Llandovery, with shaded regions showing locations of Pancake Range locality (Laurentia) and Ikla core locality (Baltica) (after Harris and Sheehan, 1998, and Kaljo and Martma, 2000).

2 Generalized Llandovery paleogeographic map of the northern Baltic region, showing the location of the Ikla core (after Kaljo and Martma, 2000).

3 Generalized Llandovery paleogeographic map of the Great Basin, showing the location of the Pancake Range section (after Harris and Sheehan, 1998)..

$4{ }^{87} \mathrm{Sr} /{ }^{86} \mathrm{Sr}$ record of the Ikla core, stratigraphy after Kaljo and Martma., 2000. Hollow points indicate "bad" data points, where Sr concentration is under 100 ppm. Generalized graptolite zones (after Koren et al., 1995): 1, acuminatus; 2 , vesiculosus; 3 , cyphus; 4, pectinatus -triangulatus; 5, argenteus; 6, convolutes; 7, sedgwickii; 8, guerichi; 9, turriculatus-crispus; 10, insectus-spiralus-crenulata-greistoniensis; 11, crenulata. Abbreviations: S., Sheinwoodian; Tely., Telychian; Rum., Rumba; Vel.,Velise.

$5 \quad \delta^{13} \mathrm{C}_{\text {carb }}$ data (Kaljo and Martma, 2000) and $\delta^{13} \mathrm{C}_{\text {org }}$ data (this study) of the Ikla core, 3 point running average through the raw data, stratigraphy after Kaljo and Martma, 2000. Abbreviations as in Figure 4 ......

$6 \quad \delta^{13} \mathrm{C}_{\text {carb }}$ data from the Pancake Range, with 3 point running average through the raw data, stratigraphy after Harris and Sheehan, 1997. Dark shaded boxes indicate darker colored dolomite lithology, light shaded boxes indicate lighter colored dolomite lithology. Member abbreviations: G, Gettel; HL, High Lake; JV, Jack Valley; D, Decathon. 
$7 \quad$ Evolution of ${ }^{87} \mathrm{Sr} /{ }^{86} \mathrm{Sr}$ through the Llandovery and lower Wenlock based on this study, with comparison to data from Azmy et al., (1999). Abbreviations as in Figure 4. Additional generalized graptolite zones (after Koren et al., 1995): 12, murchisoni; 13, riccartonensis. Additional abbreviations: Wenl., Wenlock; Shein., Sheinwoodian.

$8 \quad{ }^{87} \mathrm{Sr}{ }^{186} \mathrm{Sr}$ (this study) and $\delta^{13} \mathrm{C}_{\text {carb }}$ (Kaljo and Martma, 2000) record of the Ikla core, plotted against global eustatic curves (Johnson et al., 1996, and Loydell, 1998, respectively) and glaciations, evidenced by $\delta^{18} \mathrm{O}$ (Caputo, 1998) and glacial sediments (Azmy, 1998).

Abbreviations as in Figure 4. Additional abbreviations: H, high stand; L, low stand.

$9 \quad \delta^{13} \mathrm{C}_{\text {carb }}$ data from the Ikla core (Kaljo and Martma, 2000) plotted against $\delta^{13} \mathrm{C}_{\text {carb }}$ data from the Pancake Range (this study). Grey box is emphasizing negative excursion present in both sections, associated with Osmundsberg K-bentonite and ${ }^{87} \mathrm{Sr} /{ }^{86} \mathrm{Sr}$ inflection point. Abbreviations: Tely., Telychian; S., Sheinwoodian; Rhuddan., Rhuddanian; Sheinwo., Sheinwoodian.

10 Paleogeographic map of northern Iapetus region during the Llandovery, showing the location of the Ikla core. Large dots indicate locations of the Osmundsberg K-bentonite, showing thicknesses (in cm). Small dots represent locations of earlier Llandovery K-bentonites. Shaded area between Baltica and Scotland represents potential source area for Osmundsberg K-bentonites, and the shaded area between Nova Scotia and North America represents potential source area for North America K-bentonites (after Bergstrom et al., 1998).

11 Stratigraphy of Llandovery rocks of South Estonia (after Kaljo and Martma, 2000) correlated with generalized graptolite zones (after Koren et al., 1996) and conodont zones (after Bergstrom et al., 1998). Bold dot indicates approximate location of Osmundsberg K-bentonite (Bergstrom et al, 1998)

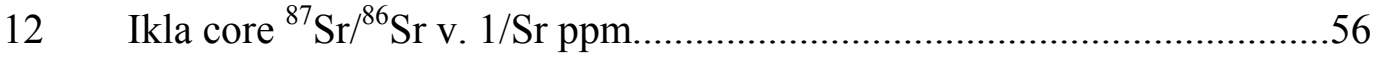

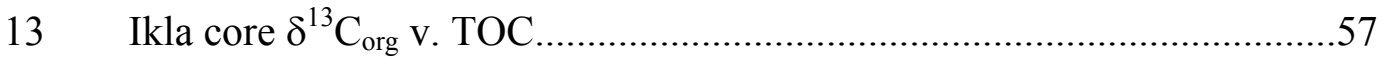

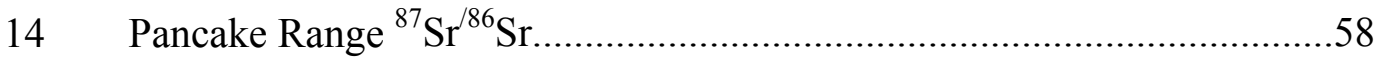

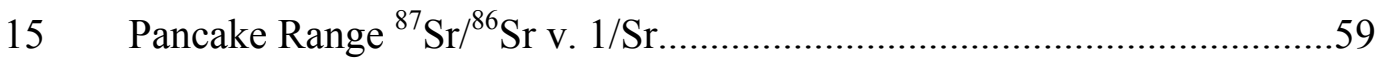




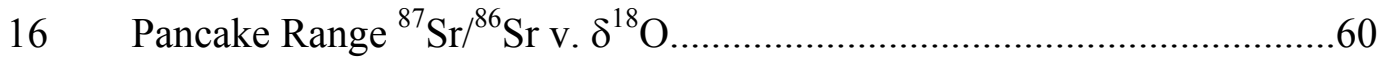






\section{CHAPTER 1}

\section{INTRODUCTION}

The early Silurian Llandovery epoch ( 443 to $428 \mathrm{Ma})$ is a time of biotic recovery following the major episodes of Late Ordovician glaciation and mass extinction (Sheehan et al., 1996; Krug and Patzkowsky, 2004). The Llandovery is generally described as a time of cyclical changes in sea level and climate (Melchin et al., 2006) related to intermittent glaciations that diminished in magnitude during the transition to a middle Paleozoic greenhouse period (Harris and Sheehan, 1996; Melchin and Holmden, 2006; Kaljo and Martma, 2000; Brand et al., 2007; Caputo, 1998). A role for atmospheric $\mathrm{CO}_{2}$ in driving these changing climatic conditions has also been emphasized (e.g., Azmy et al., 1999; Kaljo and Martma, 2000; Kiipli et al., 2004). However, the timing and causes of paleoclimatic changes with possible links to carbon cycling during the Llandoverian remain poorly understood, in part due to a lack of high-resolution, integrated geochemical proxy investigations of changes in seawater chemistry.

Sample sets of calcitic brachiopods and conodonts recovered from

localities in North America and Europe record a rising trend in the ${ }^{87} \mathrm{Sr} /{ }^{86} \mathrm{Sr}$ ratio 
throughout the Silurian, starting after the late Ordovician glaciation (Ruppel et al., 1996; Azmy et al., 1999; Veizer et al., 1999). This increase ( 0.7079 to 0.7088$)$ has been interpreted to reflect an overall warming of the Silurian climate that led to enhanced weathering of relatively radiogenic continental silicate rocks (Azmy et al., 1999). The Llandovery portion of the ${ }^{87} \mathrm{Sr} /{ }^{86} \mathrm{Sr}$ curve is characterized by exceptionally high rates of rising ${ }^{87} \mathrm{Sr} /{ }^{86} \mathrm{Sr}$ (Azmy et al., 1999), and significant inflection points have been linked to global sea level changes. However, the density of Llandovery ${ }^{87} \mathrm{Sr} /{ }^{86} \mathrm{Sr}$ analyses in previous studies is relatively low, and correlations with tectonic events (e.g., Bergstrom et al., 1998), eustatic sea level (Johnson et al., 1991), and climate are not well established.

Furthermore, although previous workers have established high resolution records of changes in marine carbonate $\delta^{13} \mathrm{C}$ that may be used to infer changes in global carbon cycling during the Llandovery (Heath et al., 1998; Kaljo and Martma, 2000; Kiipli et al., 2004), corresponding study of Sr isotope stratigraphy has not been undertaken in these same sections. In addition, because the reproducibility of these carbonate $\delta^{13} \mathrm{C}$ shifts outside of the Baltic region has not been thoroughly examined, the relative roles of global versus local effects on the observed trends remain poorly understood. Lastly, it is also possible to gain important environmental information and at the same time address potential diagenetic effects by comparing changes in carbonate $\delta^{13} \mathrm{C}$ with that of coeval organic matter $\delta^{13} \mathrm{C}$ in the same sections.

To better understand the timing and causes of rising ${ }^{87} \mathrm{Sr} /{ }^{86} \mathrm{Sr}$ during the Llandovery, the goal of this study is to construct a high resolution dataset that can 
be tied to established Llandovery biostratigraphic zones and $\delta^{13} \mathrm{C}$ stratigraphy. The primary locality utilized here is a particularly thick borehole section from Estonia (Ikla core) (Fig. 1), which was previously studied in great detail for carbonate $\delta^{13} \mathrm{C}$ and biostratigraphy by Kaljo and Martma (2000), sequence stratigraphy by Johnson et al. (1991), and volcanic event (K-bentonite) stratigraphy by Kiipli et al. (2006). The Pancake Range section in Nevada (Harris and Sheehan, 1998) (Fig. 1) provides a secondary, less biostratigraphically well constrained dataset. The results of this study reveal a previously undocumented coincidence among three distinct late Llandovery (earliest Telychian Stage) stratigraphic signals: 1) a rising inflection point in the Silurian ${ }^{87} \mathrm{Sr} /{ }^{86} \mathrm{Sr}$ curve, 2) negative excursion in $\delta^{13} \mathrm{C}$ of both carbonate and organic matter, and 3) an unusually thick K-bentonite bed representing a large-magnitude ash fall. 




Figure 1: Paleogeographic reconstruction of the Llandovery, with shaded regions showing locations of Pancake Range locality (Laurentia) and Ikla core locality (Baltica) (after Harris and Sheehan, 1998, and Kaljo and Martma, 2000). 


\section{CHAPTER 2}

\section{GEOLOGICAL SETTING}

During the Llandovery, Baltica moved to a more equatorial setting from its temperate belt setting in the middle Ordovician, which created significant climatic changes for the region (Torsvik et al., 1996). The rocks of the Llandovery in Estonia were formed along the western shoreline of the Baltica paleocontinent, and represent four distinct facies. At the most proximal locations, lagoonal dolomites and dolomitic marls mark the nearshore facies. The highenergy shoals are represented by grainstones with organic build-ups. A wide variety of limestone lithologies can be found in the shallow to mid-shelf facies, with marlstones, mudstones, and micritic limestones in the transition of the deeper outer shelf to the basin. The basin rocks are predominately graptolitic dark shales and claystones, rich in pyrite and organic carbon, which could represent anoxic conditions in this deep water setting.

The Ikla borehole section in Estonia (Fig. 2) is representative of deep shelf to basinal facies of a shallow carbonate ramp. It is the most complete Llandovery core extracted from the region because its distal location kept even the largest 


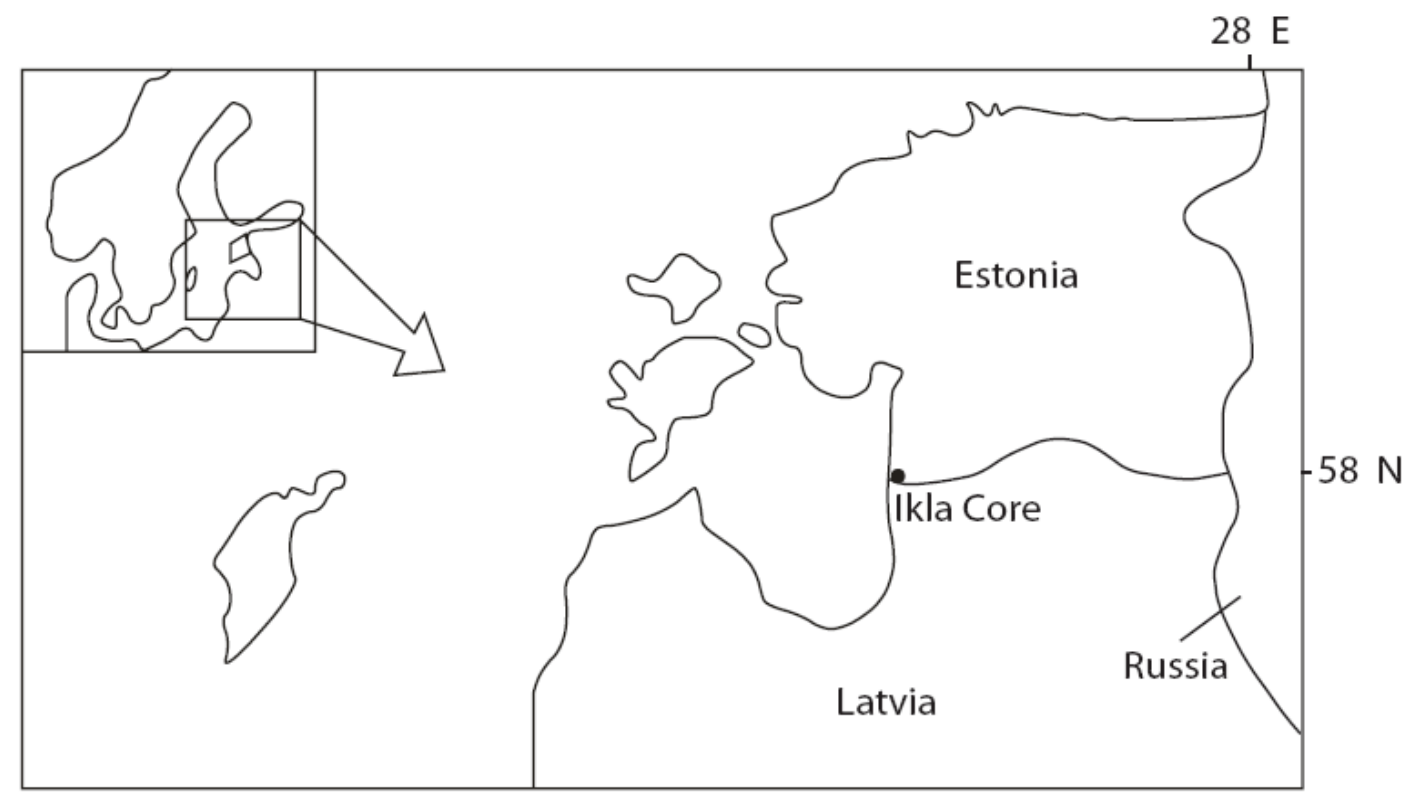

Figure 2: Generalized Llandovery paleogeographic map of the northern Baltic region, showing the location of the Ikla core (after Kaljo and Martma, 2000). 
shoreline regressions from progressing out far enough to produce unconformities (Kaljo, 2000). The preserved fauna consists primarily of deep-water graptolites and chitinozoans. Lithologies are primarily micritic limestone and marlstone with carbonate nodules at the base and top of the core sequence, transitioning into more argillaceous limestones in the middle part. Near the top of the core, two submarine disconformities are present above and below a thin sequence of argillaceous limestones, which in this locality is the Rumba formation (Kaljo and Martma, 2000).

The Ikla core is well biostratigraphically dated using generalized graptolite zones, as described by Koren et al. (1996), as well as first appearances of key chitinozoans, as described by Nestor et al. (1994). The Ohne formation is dated by appearances of the global chitinozoan Conochitina electa and the Baltica chitinozoan Dimorphograptus confertus, with Conochitina electa also present across two nearby core sections, Kirikukula and Ruhnu, providing a tie point across the region. The boundary between the Kolka formation and the Ikla formation is defined in part by the presence of Baltica chitinozoans Pernerograptus revolutus in the Kolka, and Demirastrites triangulates in the Ikla. Most important, however, is the first occurrence of the global chitinozoan Eisenackitina dolioliformis, which aids in the dating of the Rumba formation as late Aeronian to early-middle Telychian (Kaljo and Martma, 2000; Grahn, 2006). The occurrence of the brachiopod Stricklandia laevis in the Rumba formation in the nearby Viki core further constrains the age to Telychian in age (Johnson, 1991). In the Kirikukula core to the northwest of the Ikla core, the global 
chitinozoan Angochitina longicollis and Baltica chitinozoan Conochitina proboscifera also appear, in the Velise formation. In the Ruhnu core to the west of the Ikla core, the occurrence of the Baltica chitinozoans Coronograptus cyphus in the Kolka formation, Demirastrites triangulates in the Ikla formation, and Rastrites linnaei at the Staicele/Rumba boundary all help in constraining the ages of the formations. Angochitina longicollis and Conochitina proboscifera also appear in the Velise formation of the Ruhnu core, as in the Kirikukula core (Kaljo and Martma, 2000).

The studied Llandovery section in Nevada (Fig. 3) represents a marginal marine to shelf sequence deposited during platform evolution from a carbonate ramp to rimmed shelf phase (Harris and Sheehan, 1998). The Pancake Range section lies east of the margin of the rimmed shelf, which rapidly deepens to the west. Eustatic changes in sea level have been interpreted for this section using sequence stratigraphy based on methods in Johnson, 1996 and on depositional facies (Harris and Sheehan, 1998). The studied interval is contained within the Laketown Dolomite, which here can be split into five separate members, with Tony Grove Member at the base, followed by the High Lake, Gettel, upper High Lake tongue, Jack Valley, and Decathon members. Above the Laketown Dolomite is the Sevy Dolostone, which was not sampled in this study. Three sequences comprise the lower ramp phase of the Laketown Dolomite, which represent the Tony Grove and the lower half of the High Lake. Each of these sequences is dominated by burrowed packestone lithologies, with occurrences of 


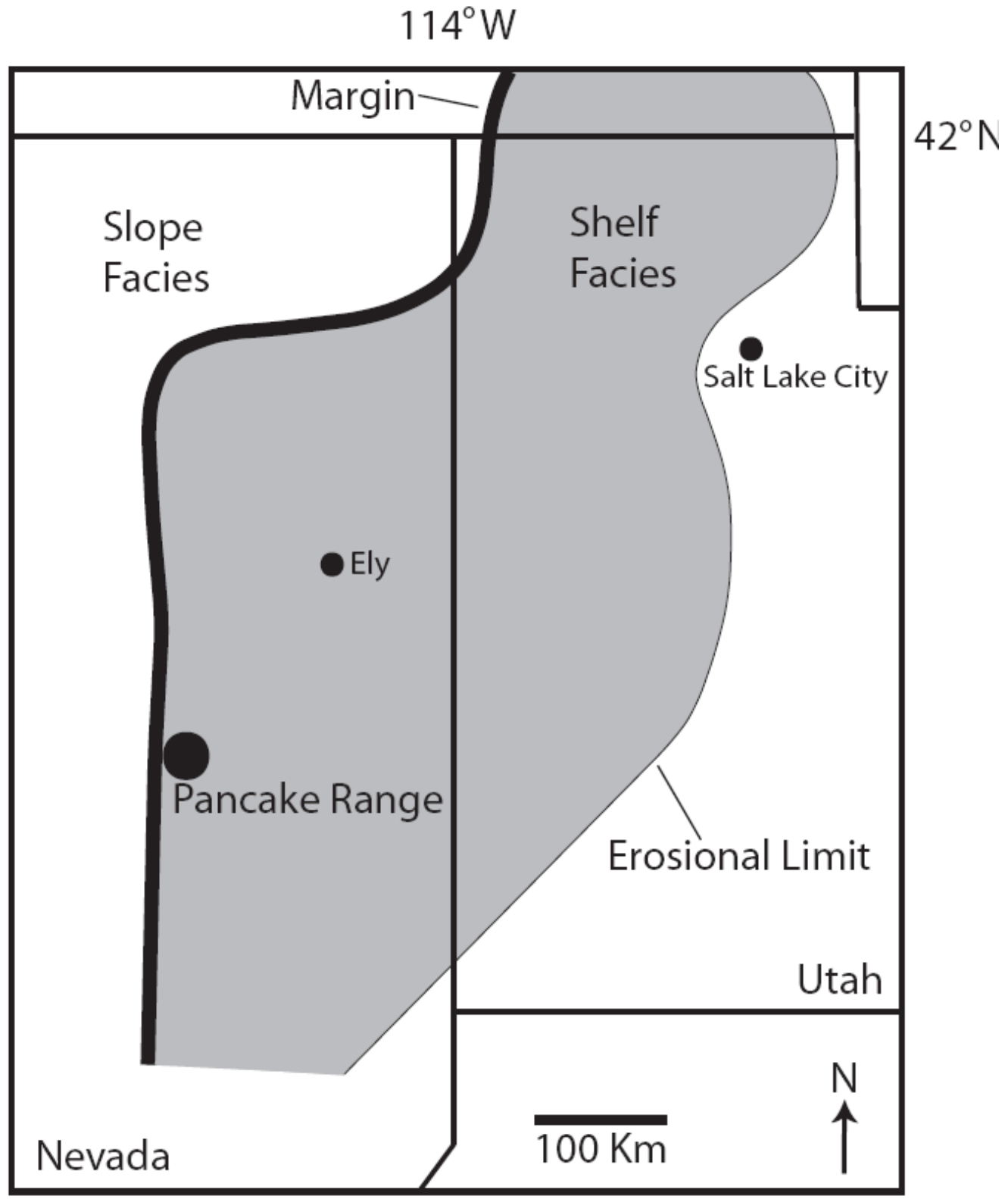

Figure 3: Generalized Llandovery paleogeographic map of the Great Basin, showing the location of the Pancake Range section (after Harris and Sheehan, 1998). 
wackestones and grainstones. Sequence boundaries are defined by surficial features, such as karst surfaces, soils, facies successions, and cyclestacking patterns, and also by large unconformities across the basin representing lowstands. The upper three sequences (upper half of the High Lake, Gettel, High Lake tongue, Jack Valley, and Decathon) during the rimmed shelf phase consist of burrowed mudstones, wackestones, packestones, and grainstones, alternating throughout the sequences (Harris and Sheehan, 1997).

The Pancake Range section is biostratigraphically dated using occurrences of macrofossil assemblages, which are also abundant throughout the section. The Rhuddanian and middle Aeronian is defined by the Virgiana dominated brachiopod interval. The upper Aeronian to lower Telychian is defined by an interval dominated by the brachiopod Pentamerus. The remainder of the Llandovery is defined by the Pentameroides brachiopod interval. While in the other intervals, associated brachiopods are rare, in the Pentameroides interval they are more common, although the Pentameroides brachiopod still dominates. The latest Llandovery and lower Wenlock are defined by a faunal change where brachiopod diversity increases, including communities such as Spirinella and Atrypina. (Sheehan, 1980). In the Pancake Range, the Ordovician-Silurian transition is marked by a rapid change in fauna, where the early Silurian cosmopolitan Virgiana community (primarily Virgiana utahensis) becomes the dominant brachiopod, and brachiopod diversity drops dramatically from the Ordovician assemblages, indicating the transition into the Silurian. In the High Lake member, Verticillopopra dasycladacean algae are present, as well as 
Amplexoides radicosi and Tryplasma sp. corals. In the Gettel, Palaeocyclus sp. and Tryplasma sp. corals have also been identified (Harris and Sheehan, 1998). Paleogeographically, this section sits on the western margin of Laurentia, near 10$15^{\circ} \mathrm{S}$ latitude (Harris and Sheehan, 1998). 


\section{CHAPTER 3}

\section{METHODS}

To determine a high-resolution data set for the ${ }^{87} \mathrm{Sr} /{ }^{86} \mathrm{Sr}$ ratio, carbonate samples from an Estonian drill core and from field collecting in the Pancake Range of central Nevada were analyzed. To obtain carbonate for analyses, rock samples were first sawed to produce flat surfaces and cleaned of any excess sediment; a drill bit was used to obtain carbonate powders for isotopic analyses. Only unaltered, fine-grained micritic components were selected for analysis. Powders were analyzed for ${ }^{87} \mathrm{Sr} /{ }^{86} \mathrm{Sr}$ and $\mathrm{Sr}$ concentration in the Radiogenic Isotope Laboratory at the Ohio State University using Sr purification and mass spectrometry procedures described by (Foland and Allen, 1991). Sr was extracted from powders using ultrapure reagents; powder aliquots of $\sim 25 \mathrm{mg}$ were pretreated with $1 \mathrm{M}$ ammonium acetate $(\mathrm{pH} 8)$ and then leached in $4 \%$ acetic acid. The leachate, which was separated from undissolved residue, was then spiked with an ${ }^{84} \mathrm{Sr}$ tracer. Samples were purified for $\mathrm{Sr}$ using a cation exchange resin and a $2 \mathrm{~N} \mathrm{HCl}$ based ion-exchange. Purified $\mathrm{Sr}$ was then loaded with $\mathrm{HCl}$ on a $\mathrm{Re}$ double-filament configuration. Isotopic compositions were measured using dynamic multicollection with a MAT-261A thermal ionization mass spectrometer. 
The Laboratory value for the SRM 987 standard is $\left({ }^{87} \mathrm{Sr} /{ }^{86} \mathrm{Sr}\right)=0.710242$ \pm 0.000010 (one-sigma external reproducibility). For the ${ }^{87} \mathrm{Sr} /{ }^{86} \mathrm{Sr}$ values the associated uncertainties given are for two-sigma mean internal reproducibilities, typically based upon 100 measured ratios. The ${ }^{87} \mathrm{Sr} /{ }^{86} \mathrm{Sr}$ reported ratios are normalized for instrumental fractionation using a normal $\mathrm{Sr}$ ratio of ${ }^{86} \mathrm{Sr} /{ }^{88} \mathrm{Sr}=$ 0.119400. No modifications to the measured normalized ${ }^{87} \mathrm{Sr} /{ }^{86} \mathrm{Sr}$ ratios have been made.

For organic carbon isotope analysis, samples were cut into billets using a rock saw, and the billets were cleaned using a sonicator. After drying, each sample was powdered using a mortar and pestle or an electric drill. In Dr. Ken Foland's Radiogenic Isotope Laboratory at the Ohio State University, one gram of powder was weighed out in $50 \mathrm{~mL}$ FALCON test tubes and dissolved in $20 \mathrm{~mL}$ of $6 \mathrm{~N} \mathrm{HCl}$ and centrifuged. The remaining residue was then washed three times using $20 \mathrm{~mL}$ of water and a centrifuge. The samples were then dried overnight in an $80^{\circ} \mathrm{C}$ oven, and homogenized using a mortar and pestle once dry. Each sample was then weighed on a micro balance, depending on organic content, in Dr. Andrea Grottoli's Stable Isotope Biogeochemistry Laboratory at the Ohio State University, and analyzed for organic ${ }^{13 / 12} \mathrm{C}$ ratios using a Finnigan Delta Plus IV coupled with a Costech Elemental Analyzer with continuous flow by CONFLOIII (EA-SIRMS).

For $\delta^{13} \mathrm{C}_{\text {carb}}$, samples of the Pancake Range section were drilled on clean carbonate surfaces for approximately $500 \mu \mathrm{g}$ of powder. For each sample, A 75$95 \mu \mathrm{g}$ subsample was analyzed for $\delta^{18} \mathrm{O}\left(\delta^{18} \mathrm{O}=\right.$ permil deviation of ${ }^{18} \mathrm{O}:{ }^{16} \mathrm{O}$ 
relative to to Vienna Peedee Belmnite Limestone standard (V-PDB)) and $\delta^{13} \mathrm{C}$ $\left(\delta^{13} \mathrm{C}=\right.$ permil deviation of ${ }^{13} \mathrm{C}:{ }^{12} \mathrm{C}$ relative to $\left.\mathrm{V}-\mathrm{PDB}\right)$ using an automated Carbonate Kiel device coupled to a Finnigan Delta IV Plus stable isotope ratio mass spectrometer in Dr. Andrea Grottoli's Stable Isotope Biogeochemistry Laboratory at The Ohio State University. Samples were acidified under vacuum with $100 \%$ ortho-phosphoric acid, the resulting $\mathrm{CO}_{2}$ cryogenically purified, and delivered to the mass spec. Approximately $10 \%$ of all samples were run in duplicate. The standard deviation of repeated measurements of an internal standard was $\pm 0.03 \%$ for $\delta^{13} \mathrm{C}$ and $\pm 0.09 \%$ for $\delta^{18} \mathrm{O}$. 


\section{CHAPTER 4}

\section{RESULTS}

$\mathrm{Sr}$ isotope data from Ikla core show significant variability in the Rhuddanian portion of the core, ranging from 0.707986 to 0.708341 , averaging about 0.7081 . The Aeronian is much less variable, with values staying between 0.708027 and 0.708127 . In the basal Telychian (Rumba Formation), a rapid shift to more radiogenic values occurs, trending from .708075 to .708441 (Fig 4).

One of the most important issues with analyzing trends in $\mathrm{Sr}$ is the potential for diagenetic influences to alter the primary seawater values. In general, samples that are diagenetically altered are likely to appear more radiogenic than that of the paleoocean. When the rock is diagenetically altered, Sr concentration is in most cases reduced, and younger, more radiogenic values overprint the original ratio (Montanez et al., 1996; Azmy et al., 1999; Brand et al., 2006; Halverson et al., 2007). The preferred criteria used to address diagenesis in this study were the Sr concentrations of the analyzed rock, which was measured along with the isotopic ratio. This method was used over other commonly used diagenetic checks $\left(\mathrm{Mn} / \mathrm{Sr}, \mathrm{Sr} / \mathrm{Ca}, \delta^{18} \mathrm{O}\right)$ for a variety of reasons. High $\mathrm{Mn} / \mathrm{Sr}$ might be indicative of anoxic carbonate precipitation and not diagenetic 
Figure 4: ${ }^{87} \mathrm{Sr} /{ }^{86} \mathrm{Sr}$ record of the Ikla core, stratigraphy after Kaljo and Martma., 2000. Hollow points indicate "bad" data points, where Sr concentration is under 100 ppm. Generalized graptolite zones (after Koren et al., 1995): 1, acuminatus; 2, vesiculosus; 3, cyphus; 4, pectinatus-triangulatus; 5, argenteus; 6, convolutes; 7, sedgwickii; 8, guerichi; 9, turriculatus-crispus; 10, insectus-spiralus-crenulatagreistoniensis; 11, crenulata. Abbreviations: S., Sheinwoodian; Tely., Telychian; Rum., Rumba; Vel., Velise. 




$\square$ micritic limestone

E-1

- $\exists$ marlstone/mudstone

thicker argillaceous
intercalcations




alteration, and $\mathrm{Sr} / \mathrm{Ca}$ and $\delta^{18} \mathrm{O}$ do not account for possible dolomitization, as $\mathrm{Sr}$ and $\mathrm{Ca}$ concentrations are jointly reduced by the process, and $\delta^{18} \mathrm{O}$ values increase by $2-4 \%$, which can falsely identify a sample as unaltered. However, since initial ocean concentrations of $\mathrm{Sr}$ can differ, as well as the original mineralogy of the oceans (calcite vs. aragonite seas), the criteria for diagenesis is variable. Based upon the range of $\mathrm{Sr}$ concentrations in the Ikla core rocks, a threshold of $100 \mathrm{ppm}$ was used to exclude data points from the plotted Llandovery ${ }^{87} \mathrm{Sr} /{ }^{86} \mathrm{Sr}$ curve of the Ikla core (Halverson et al., 2007; Montanez et al., 1996). Also, values that were less than $100 \mathrm{ppm}$ appeared to be more radiogenic than the surrounding data points, giving confidence to this criteria selection (Halverson et al., 2007; Montanez et al., 1996). In addition, the data follows distinct trends through time, particularly in the Telychian, where values become more radiogenic as they get younger. It would be statistically improbable for these trends to be caused by diagenetic alteration, giving additional evidence that the values produced in this study are representative of actual paleoocean ${ }^{87} \mathrm{Sr} /{ }^{86} \mathrm{Sr}$ values.

The $\delta^{13} \mathrm{C}_{\text {org }}$ curve from the Ikla core exhibits both similarities (Telychian portion) and differences (Rhuddanian-Aeronian) when compared with the $\delta^{13} \mathrm{C}_{\text {carb }}$ curve generated by Kaljo and Martma (2000) (Fig 5). This general difficulty in matching signals is likely due in part to the low resolution of the data compared to $\delta^{13} \mathrm{C}_{\text {carb }}$ and the fact that $\delta^{13} \mathrm{C}_{\text {org }}$ is likely to be inherently more noisy than $\delta^{13} \mathrm{C}_{\text {carb }}$ due to inhomogeneities in the materials analyzed (e.g., Joachimski et al. 2002). It 


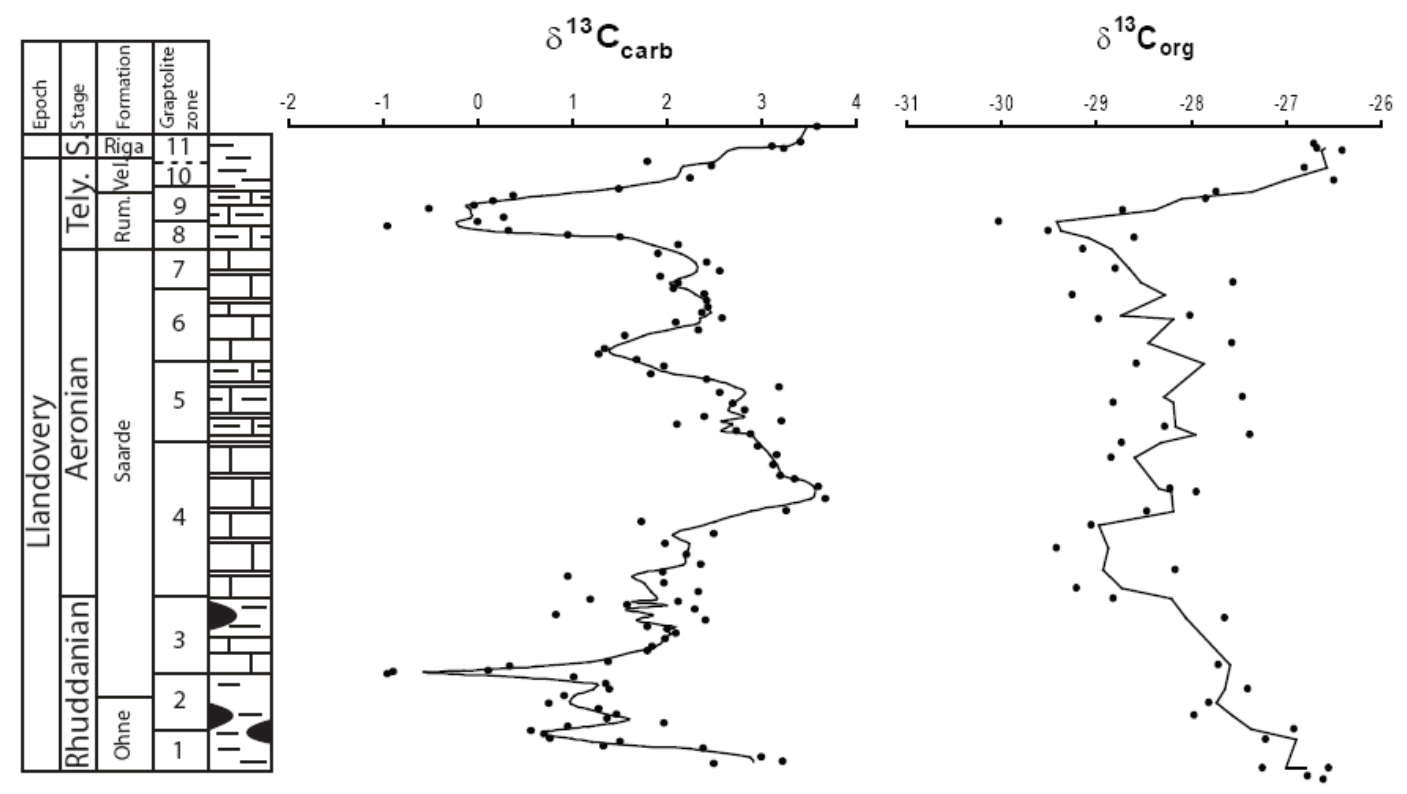

Figure 5: $\delta^{13} \mathrm{C}_{\text {carb }}$ data (Kaljo and Martma, 2000) and $\delta^{13} \mathrm{C}_{\text {org }}$ data (this study) of the Ikla core, 3 point running average through the raw data, stratigraphy after Kaljo and Martma, 2000. Abbreviations as in Figure 4. 
is also possible that the differences in the carbon isotope curves of carbonates and organic matter are related to changes in atmospheric $\mathrm{CO}_{2}$ that can affect photosynthetic fractionation (Kump and Arthur, 1999; Joachimski et al. 2002). Here, we wish to emphasize the significant parallel changes in the two curves in the Telychian. A significant $\delta^{13} \mathrm{C}$ minimum occurs in the earliest Telychian

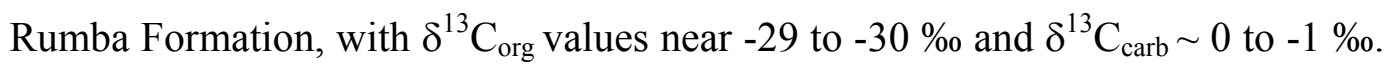
Both curves begin to increase rapidly in the middle Telychian into the early Wenlock, with $\delta^{13} \mathrm{C}_{\text {org }}$ rising by a magnitude of $3.5 \%$, and $\delta^{13} \mathrm{C}_{\text {carb }}$ by $4.5 \%$. Presumably, thismarks the beginning of the Ireviken excursion, which has been shown to show values of $3 \%$ and $4 \%$ in the early Wenlock. TOC ranges from $0.06 \%$ to $0.34 \%$ and shows no discernable trend in relation to $\delta^{13} \mathrm{C}_{\text {org }}$ values (App. B), which indicates a reliable signal recovery. The parallel changes in both carbonate and organic $\delta^{13} \mathrm{C}$ is itself a reliable indicator of preservation of primary seawater values (Joachimski et al., 2002).

While the $\delta^{13} \mathrm{C}_{\text {carb }}$ data from the Pancake Range section is less biostratigraphically controlled, the negative excursion present in the Ikla core appears to be present here as well, showing values of approximately $0 \%$ in the earliest Telychian. The Pancake Range data also trends to more positive values after this negative excursion, reaching $2.5 \%$ in the late Telychian, and even $3 \%$ in the early Wenlock, similar to the trends in the Ikla core (Fig 6). 


\section{Pancake Range}
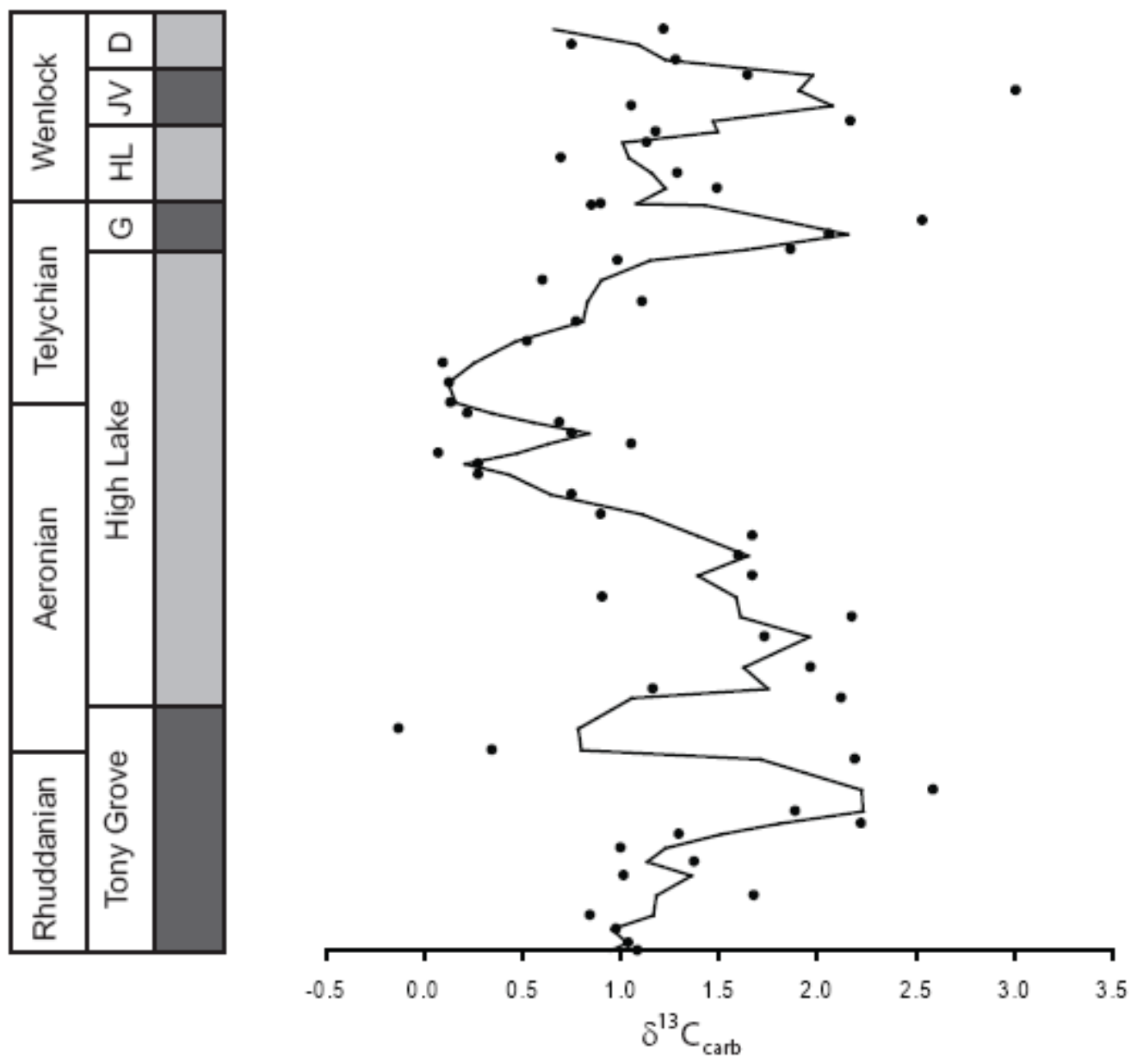

Figure 6. $\delta^{13} \mathrm{C}_{\text {carb }}$ data from the Pancake Range, with 3 point running average through the raw data, stratigraphy after Harris and Sheehan, 1997. Dark shaded boxes indicate darker colored dolomite lithology, light shaded boxes indicate lighter colored dolomite lithology. Member abbreviations: G, Gettel; HL, High Lake; JV, Jack Valley; D, Decathon. 


\section{CHAPTER 5}

\section{DISCUSSION}

The establishment of a high-resolution Sr isotope curve for the Llandovery from the Ikla core in Estonia reveals that much of the previously recognized overall ${ }^{87} \mathrm{Sr} /{ }^{86} \mathrm{Sr}$ rise (Azmy et al., 1999) is focused in the earliest Telychian Stage (Fig. 7). Furthermore, by analyzing Sr isotopes as well as organic carbon isotopes in the same core that was previously analyzed for $\delta^{13} \mathrm{C}_{\text {carb }}$ (Kaljo and Martma, 2000), it is possible to establish a temporal coincidence among major changes in all three records during the Telychian (Fig. 8). Although the studied interval here includes the earliest Silurian Rhuddanian Stage, the isotope signals from this interval in the Ikla core are clearly more complex than succeeding stages and will require additional study to discern whether these trends indeed record primary, global changes in seawater chemistry or secondary (local) influences. Thus, in the discussion which follows here, the focus is on the records spanning the Aeronian and Telychian Stages only.

The observed $\mathrm{Sr}$ isotope increase in the early Telychian can be potentially linked to changes in rates of continental weathering, hydrothermal interaction with basaltic rocks, or changes in the ${ }^{87} \mathrm{Sr} /{ }^{86} \mathrm{Sr}$ of the continental source material 


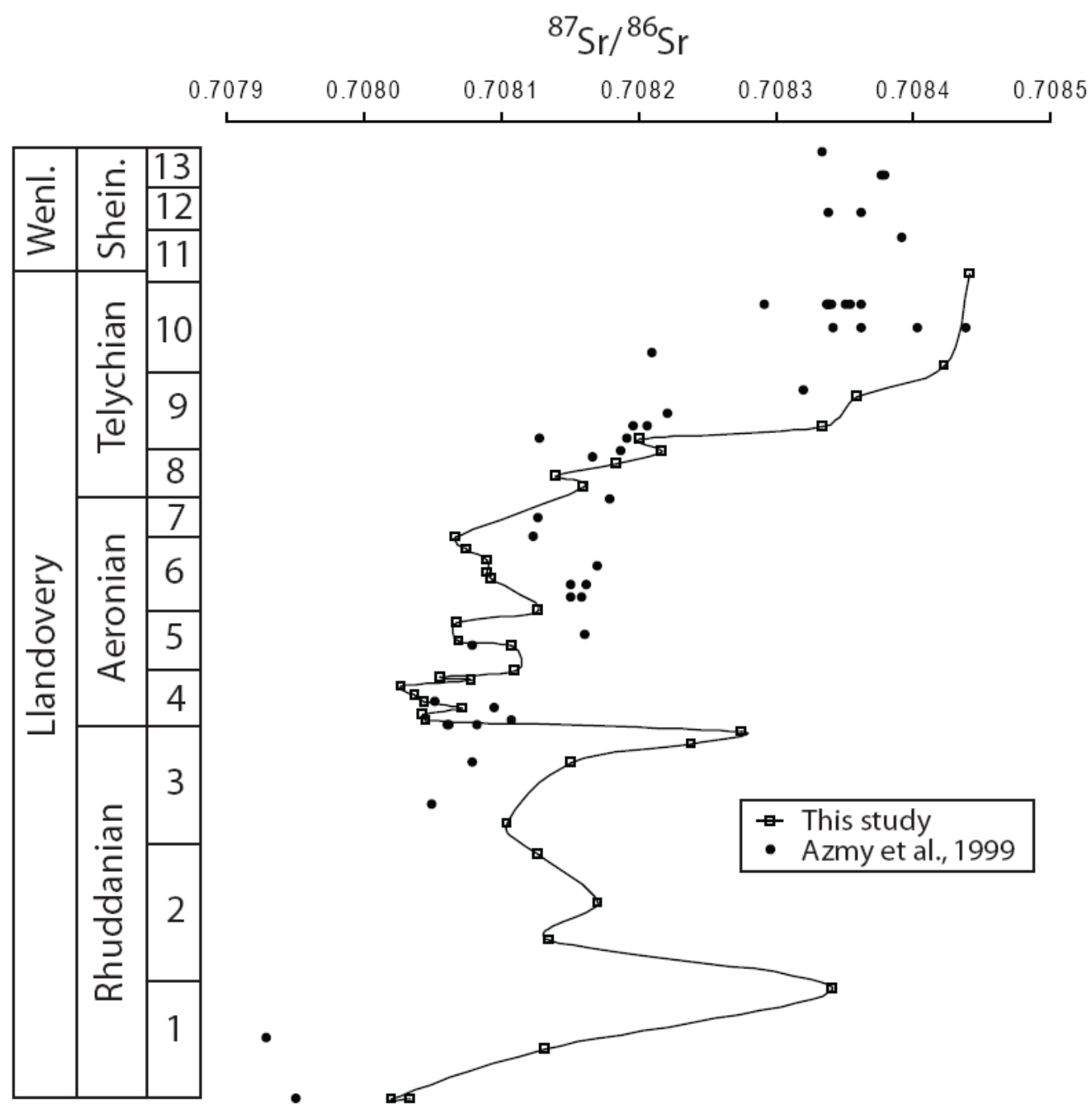

Figure 7: Evolution of ${ }^{87} \mathrm{Sr} /{ }^{86} \mathrm{Sr}$ through the Llandovery and lower Wenlock based on this study, with comparison to data from Azmy et al., (1999). Abbreviations as in Figure 4. Additional generalized graptolite zones (after Koren et al., 1995): 12, murchisoni; 13, riccartonensis. Additional abbreviations: Wenl., Wenlock; Shein., Sheinwoodian. 
Figure 8: ${ }^{87} \mathrm{Sr}{ }^{186} \mathrm{Sr}$ (this study) and $\delta^{13} \mathrm{C}_{\text {carb }}$ (Kaljo and Martma, 2000) record of the Ikla core, plotted against global eustatic curves (Johnson et al., 1996, and Loydell, 1998, respectively) and glaciations, evidenced by $\delta^{18} \mathrm{O}$ (Caputo, 1998) and glacial sediments (Azmy, 1998). Abbreviations as in Figure 4. Additional abbreviations: H, high stand; L, low stand. 


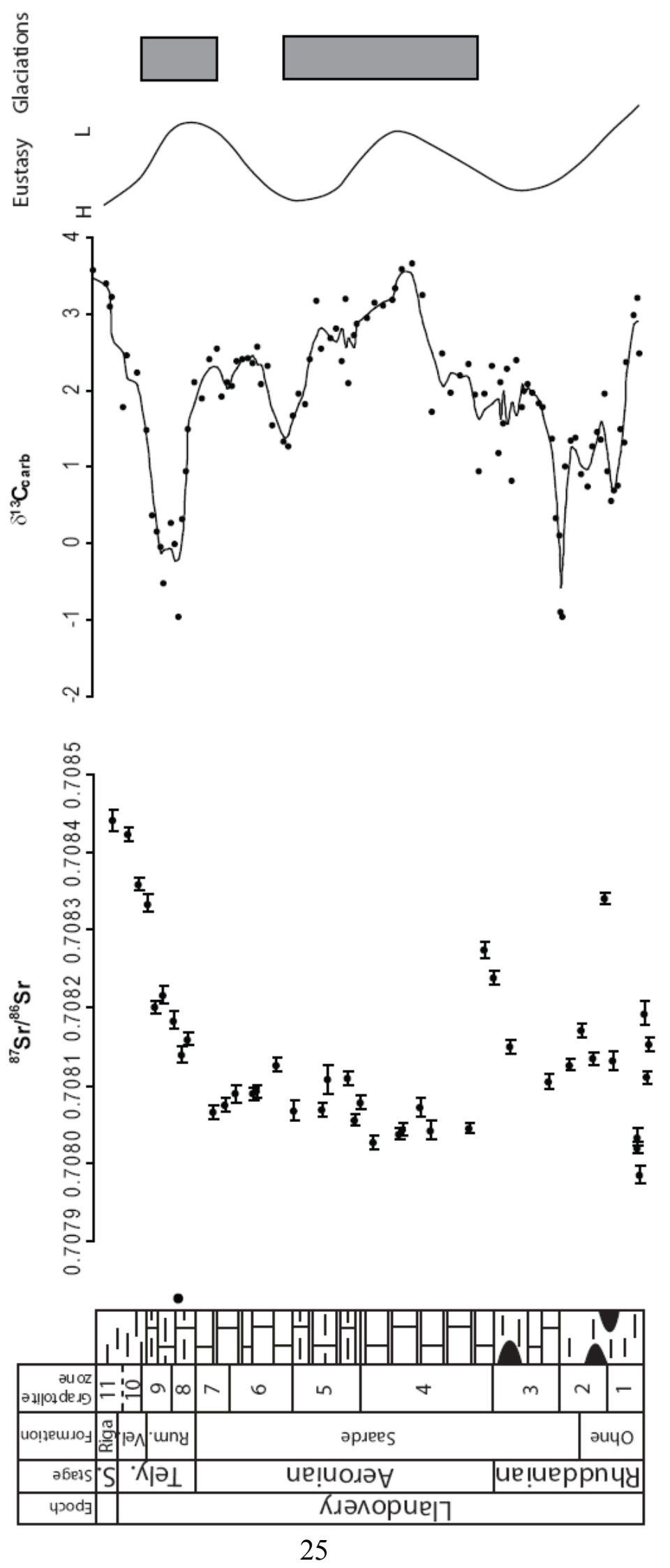


being weathered (Richter et al., 1992; Hodell et al., 1990; Farrell et al., 1992). The weathering of continental silicate rocks will introduce relatively radiogenic $\mathrm{Sr}$ (higher ${ }^{87} \mathrm{Sr} /{ }^{86} \mathrm{Sr}$ ratio) into rivers. The riverine flux may thus increase during tectonic uplift resultant from continental collisions, which may also expose older, highly radiogenic (high ${ }^{87} \mathrm{Sr}{ }^{186} \mathrm{Sr}$ ) silicates (Raymo and Ruddiman, 1988). Hydrothermal interaction with newer basaltic ocean crust, or the weathering of continental mafic volcanics both increase the flux of less radiogenic $\mathrm{Sr}$ to the oceans (Palmer and Elderfield, 1984), and therefore could have decreased in magnitude to contribute to the early Telychian ${ }^{87} \mathrm{Sr} /{ }^{86} \mathrm{Sr}$ rise.

The stratigraphic evidence from K-bentonite studies of Silurian strata (Bergstrom et al., 1998) reveal a potential link between the early Telychian increase in ${ }^{87} \mathrm{Sr} /{ }^{86} \mathrm{Sr}$ and convergent margin tectonics. K-bentonite beds represent short-lived ash falls that can be correlated over long distances by geochemical "fingerprinting" techniques (Huff et al., 1998). Llandovery K-bentonite horizons are known from European (Baltic) sections and the Appalachians of North America (Bergstrom et al., 1992). However, by far the largest and most significant Silurian K-bentonite is known as the Osmundsberg K-bentonite bed. The Osmundsberg K-bentonite is identifiable from a wide range of localities, including Sweden, Estonia, Norway and the British Isles (Bergstrom et al., 1992; Bergstrom et al, 1998; Lehnert et al., 1999) (Fig. 8). This bed occurs at thicknesses up to $115 \mathrm{~cm}$ at some localities, and has been traced over a distance of $2000 \mathrm{~km}$ into Estonia (Bergstrom et al., 1998). The Osmundsberg K-bentonite bed has been interpreted to represent a large scale felsic volcanic event, with an 
ash fall that lasted a few weeks (Huff et al., 1998). This large-magnitude ash fall is well dated by biostratigraphy to the earliest Telychian lower to middle turriculatus graptolite zone (Bergstrom et al., 1998). Significantly, the Osmundsberg K-bentonite bed also occurs in the same sedimentary formation in the Baltic region (Rumba formation) in which the rising ${ }^{87} \mathrm{Sr} /{ }^{86} \mathrm{Sr}$ values are recorded in the Ikla core (Fig 4). The weathering of early Silurian felsic volcanics with high ${ }^{87} \mathrm{Sr} /{ }^{86} \mathrm{Sr}$ ratios thus may have been a contributing factor to the coincident rise in ${ }^{87} \mathrm{Sr} /{ }^{86} \mathrm{Sr}$. However, because the ${ }^{87} \mathrm{Sr} /{ }^{86} \mathrm{Sr}$ continues to rise through the remainder of the Silurian, input of radiogenic Sr from the weathering of uplifted non-volcanic silicates could sustain this increase.

The weathering of uplifted non-volcanic, old (radiogenic) silicates from Silurian continent-continent collisions (Ettensohn et al., 1998; Ettensohn et al., 2002) may have been the critical factor in increasing ${ }^{87} \mathrm{Sr}{ }^{186} \mathrm{Sr}$ (Richter et al., 1992). Furthermore, it has been shown that modern rivers draining high relief regions associated with active plate boundaries in tropical to sub-tropical latitudes have some of the highest physical and chemical erosion rates in the world (Lyons et al., 2005). The uplifted terranes that may have played a role in the early Telychian Sr increase are in tropical to sub-tropical latitudes (Fig. 8). An early Telychian age for major tectonic changes is consistent with the Silurian tectonic evolution of Laurentia that has been described based on evidence from the northern and central Appalachians (Ettensohn and Brett, 1998). This evidence includes $\mathrm{U}-\mathrm{Pb}$ dating of volcanism from granites from the New Brunswick portion of the Canadian Appalachians (Bevier and Whalen, 1990), deformation, 
plutonism, and foreland basin fill (Ettensohn and Brett, 1998). While the final suturing of Baltica and Laurentia, referred to as the Caledonian orogeny, occurred in the late Silurian/early Devonian, it is believed that initial collision actually occurred in the Telychian and is referred to as the Scandian orogeny (Gee, 1975). The Scandian orogeny is dated to early Telychian, as is the Salinic tectophase I, and likely the two represent the same tectonic event represented on separate parts of the Caledonian suture (Ettensohn and Brett, 1998). The Salinic tectophase is most likely a result of oblique subduction of Avalonian terranes under Laurentia.

The best evidence for a causal connection between the Salinic orogeny and the early Telychian increase in ${ }^{87} \mathrm{Sr} /{ }^{86} \mathrm{Sr}$ is based on the age of a major tectonic unconformity in the sedimentary succession of the Appalachian basin. This unconformity, at the base of the Clinton Group in the eastern United States which is dated to early Telychian, represents the uplift and migration of the forebulge that formed during the beginning stages of the flexural subsidence that created the Appalachian foreland basin. A tectonic origin for this sequence boundary is also supported by an overlying condensed section, indicative of flexural subsidence and relative sea-level rise that cut off sediment supply to the shelf and basin. Evidence for the late Telychian Scandian orogeny is found in Greenland, Norway, Scandinavia (late Llandovery bentonites), and Sweden. This suggests the early Silurian was an important period of global tectonic reorganization, primarily along the Caledonian suture (Ettensohn and Brett, 1998), and may have continued to drive ${ }^{87} \mathrm{Sr} /{ }^{86} \mathrm{Sr}$ to more radiogenic values throughout the Telychian and for the remainder of the Silurian. The 
Osmundsberg K-bentonite serves as the best indicator of the effect of early Silurian tectonics to the rise in ${ }^{87} \mathrm{Sr} /{ }^{86} \mathrm{Sr}$, as uplift would follow these subduction sourced volcanic 


\section{CHAPTER 6}

\section{RELATION TO CLIMATE, SEA LEVEL, AND CARBON CYCLING}

The ash fall indicated by the Osmundsberg K-bentonite could have influenced the Sr flux into the oceans, but may have also had a significant effect on carbon cycling that produced important climatic feedbacks and linkages between the atmosphere and oceans in the early Telychian. A large influx of volcanic $\mathrm{CO}_{2}$ to the atmosphere would be low in $\delta^{13} \mathrm{C}(-5 \%$ ) (Payne and Kump 2007), and could have contributed to the observed negative shifts in the $\delta^{13} \mathrm{C}$ records of carbonate and organic matter in the Ikla core (Rumba Formation). A similar negative $\delta^{13} \mathrm{C}$ excursion during this time is also seen in the Canadian Arctic (Melchin et al., 2006), other studied Baltica cores (Kaljo and Martma, 2000), as well as in the $\delta^{13}$ Ccarb data produced from the Pancake Range (Fig 9; all these observations indicate a global event. This also adds an additional method to correlate multiple sections which use different biostratigraphic zonations. This volcanic outgassing scenario was modeled to explain apparently global negative $\delta^{13} \mathrm{C}$ excursions in the early Triassic (Payne and Kump, 2007). 
Glaciation during the late Aeronian-early Telychian interval has been proposed by Caputo (1998), and may also relate ultimately to the ongoing tectonic events of this time period. Although the cause of the glaciation is not well understood, the initial cooling likely began in response to the enhanced bioproductivity during the preceding Aeronian Stage recognized throughout the east Baltic epicontinental sea (Kiipli et al., 2004). This productivity increase caused an increase in organic carbon burial that is supported by the broad positive $\delta^{13} \mathrm{C}$ excursion in the mid-Aeronian seen in the Ikla core and elsewhere (Kaljo and Martma, 2000). Therefore, a decrease in atmospheric $\mathrm{CO}_{2}$ likely occurred just before the start of the Telychian and may have positioned the climate system at a tipping point (e.g., Kump and Arthur, 1999). The Osmundsberg K-bentonite (Bergstrom et al., 1998) may thus provide a causal linkage among a major volcanic eruption, negative $\delta^{13} \mathrm{C}$ excursion, and rising inflection in the ${ }^{87} \mathrm{Sr} /{ }^{86} \mathrm{Sr}$ curve (Fig. 9).

The negative shift in the Rumba formation is followed by a prominent positive $\delta^{13} \mathrm{C}$ excursion in the remaining Telychian strata of the Ikla core, which has been identified as the beginning of the Ireviken excursion in the nearby Ruhnu core in the early Wenlock (Kaljo et al., 2003). This positive excursion is consistent with post-glacial warming that triggered enhanced marine anoxia and increased productivity from regenerated phosphate, as modeled by Payne and Kump (2007) for similar cyclic changes in Early Triassic carbon isotopes. The positive $\delta^{13} \mathrm{C}$ shift after deposition of the Rumba formation also corresponds to a continuation of rising ${ }^{87} \mathrm{Sr} /{ }^{86} \mathrm{Sr}$ in the rest of the Telychian and could indicate a 


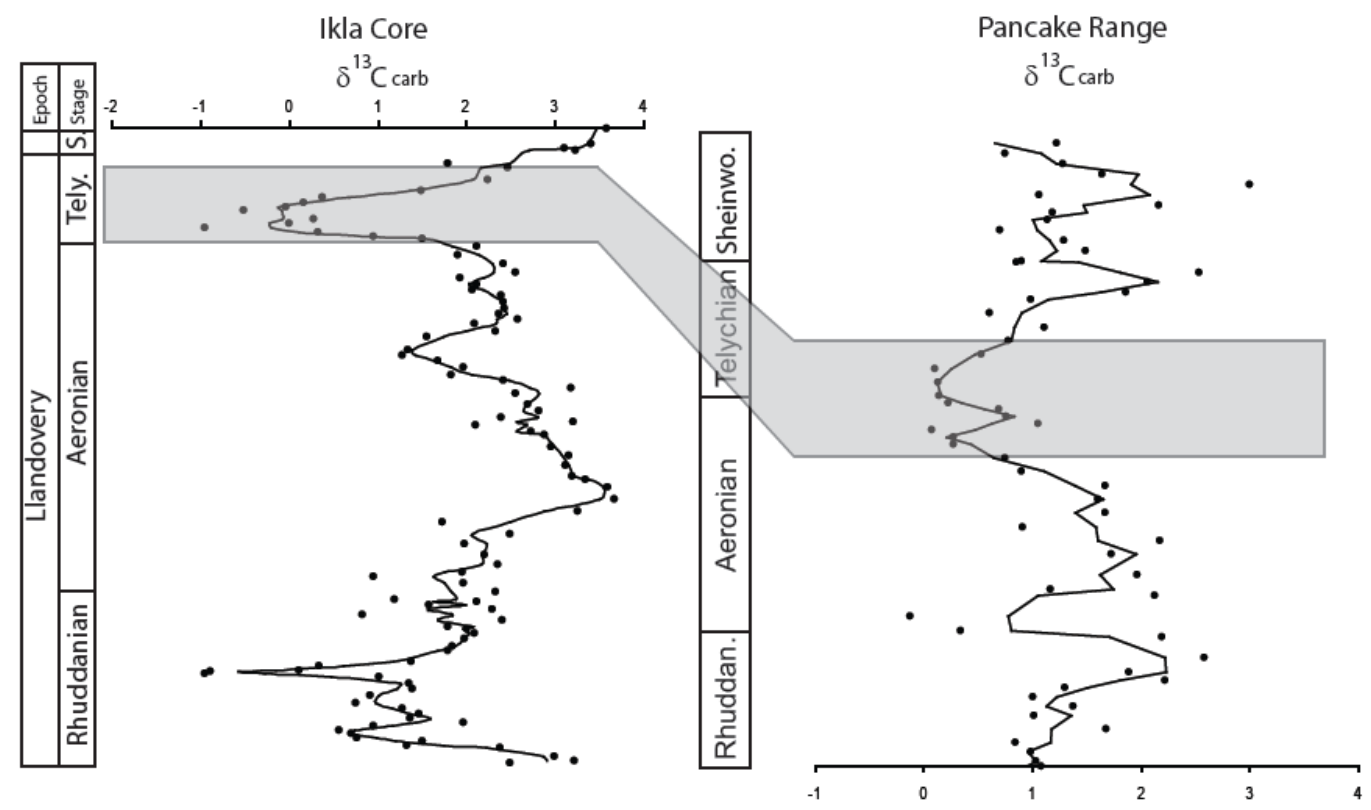

Figure 9. $\delta^{13} \mathrm{C}_{\text {carb }}$ data from the Ikla core (Kaljo and Martma, 2000) plotted against $\delta^{13} \mathrm{C}_{\text {carb }}$ data from the Pancake Range (this study). Grey box is emphasizing negative excursion present in both sections, associated with Osmundsberg K-bentonite and ${ }^{87} \mathrm{Sr} /{ }^{86} \mathrm{Sr}$ inflection point. Abbreviations: Tely., Telychian; S., Sheinwoodian; Rhuddan., Rhuddanian; Sheinwo., Sheinwoodian. 


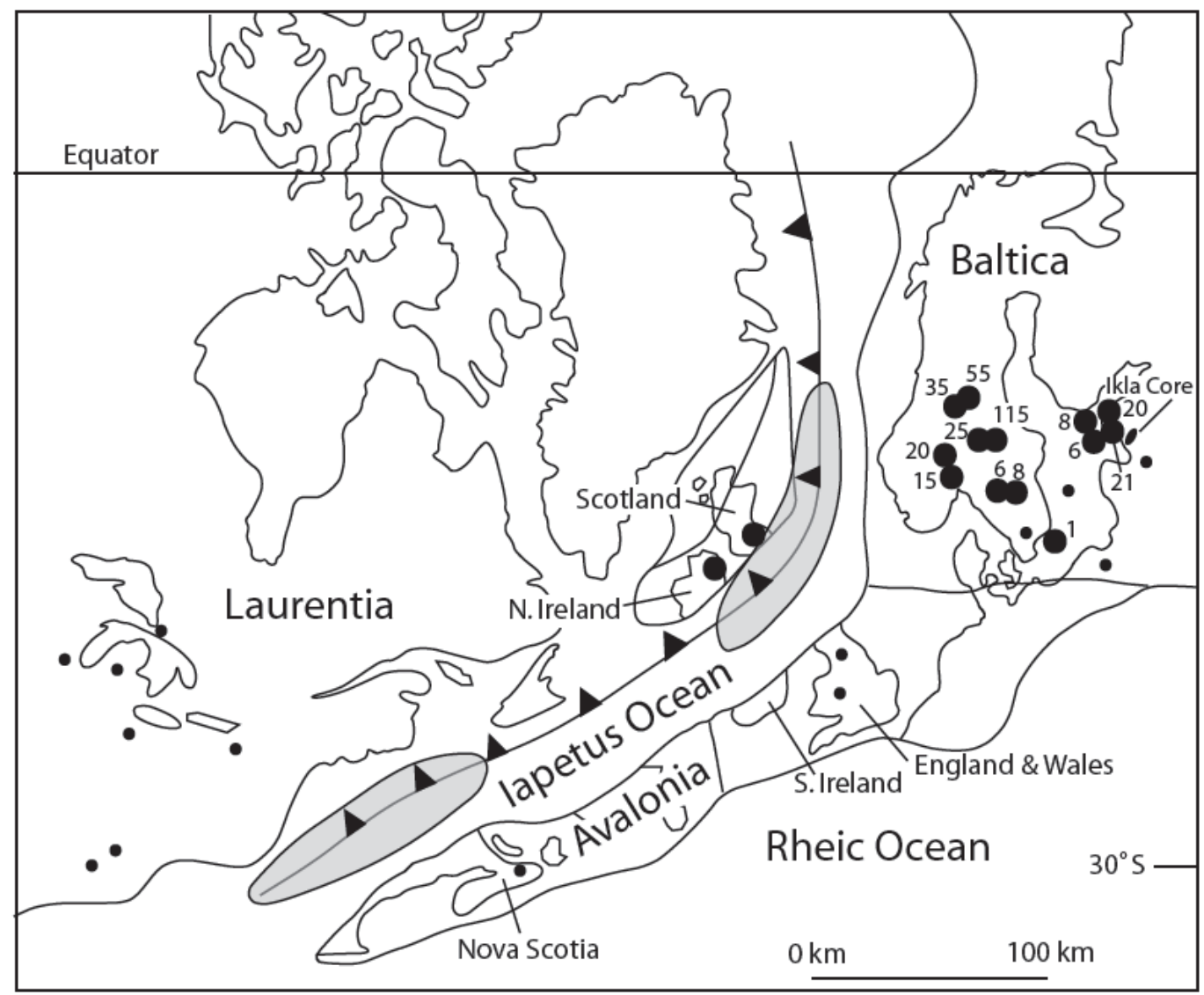

Figure 10: Paleogeographic map of northern Iapetus region during the

Llandovery, showing the location of the Ikla core. Large dots indicate locations of the Osmundsberg K-bentonite, showing thicknesses (in $\mathrm{cm}$ ). Small dots represent locations of earlier Llandovery K-bentonites. Shaded area between Baltica and Scotland represents potential source area for Osmundsberg Kbentonites, and the shaded area between Nova Scotia and North America represents potential source area for North America K-bentonites (after Bergstrom et al., 1998). 


\begin{tabular}{|c|c|c|c|c|}
\hline Stages & $\begin{array}{l}\text { Baltic } \\
\text { Stages }\end{array}$ & Formations & Graptolite Zones & Conodont Zones \\
\hline \multirow{4}{*}{ 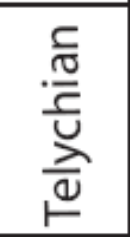 } & \multirow{4}{*}{ Adavere } & \multirow{2}{*}{ Velise } & \multirow{2}{*}{$\begin{array}{l}\text { insectus- spiralis } \\
\text { crenulata- griestoniensis }\end{array}$} & P.amorphognathoides. \\
\hline & & & & P. celloni \\
\hline & & \multirow[b]{2}{*}{ Rumba } & turriculatus-crispus & \multirow[b]{2}{*}{ D. staurognathoides } \\
\hline & & & guerichi & \\
\hline \multirow{4}{*}{ 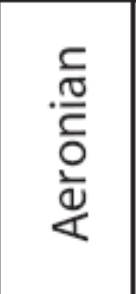 } & \multirow{5}{*}{ Raikkula } & \multirow[b]{2}{*}{ Staicele } & sedgwickii & \multirow{3}{*}{$\begin{array}{l}\text { I. discreta- } \\
\text { I. deflecta }\end{array}$} \\
\hline & & & convolutus & \\
\hline & & \multirow{3}{*}{ 总 Lemme } & argenteus & \\
\hline & & & pectinatus- triagulatus & \multirow{4}{*}{ D. kentuckyensis } \\
\hline \multirow{3}{*}{ 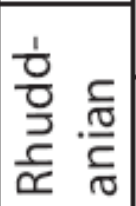 } & & & cyphus & \\
\hline & \multirow{2}{*}{ Juuru } & \multirow{2}{*}{ Ohne } & vesiculosus & \\
\hline & & & acuminatus & \\
\hline
\end{tabular}

Figure 11: Stratigraphy of Llandovery rocks of South Estonia (after Kaljo and Martma, 2000) correlated with generalized graptolite zones (after Koren et al., 1996) and conodont zones (after Bergstrom et al., 1998). Bold dot indicates approximate location of Osmundsberg K-bentonite (Bergstrom et al, 1998). 
periodically important role for enhanced warming in increasing weathering of radiogenic continental silicate rocks. 


\section{CHAPTER 7}

\section{CONCLUSION}

High resolution data of ${ }^{87} \mathrm{Sr} /{ }^{86} \mathrm{Sr}$ during the Llandovery shows that the change in $\mathrm{Sr}$ is more complex than previously thought, and aids in interpreting the paleoclimatic and tectonic reasons for this shift. The presence of the Osmundsberg K-bentonite and the negative excursion in $\delta^{13} \mathrm{C}_{\text {carb }}$ in the Rumba formation of the early Telychian in the Ikla core coincide with the start of the rapid positive shift in Sr. This implies that large scale volcanics were present, and that weathering of these volcanics potentially caused the onset of the rise in Sr. These volcanics would have served as a precursor to continental subduction in the early Silurian, which following the Taconic orogeny of the late Ordovician/early Silurian, would have exposed older radiogenic Sr to be weathered, and thus continued the increase in radiogenic values. During the Aeronian, bioproductivity was high, and $\mathrm{C}$ burial increased, lowering atmospheric $\mathrm{CO}_{2}$ into the Telychian which, sent the climate into a glaciation, which contributed to the increased weathering of continental silicate rocks as sea level regressed. Associated with the increase in ${ }^{87} \mathrm{Sr} /{ }^{86} \mathrm{Sr}$ is a large negative excursion in $\delta^{13} \mathrm{C}$, which could be the result of an increased flux of light $\mathrm{CO}_{2}$ into the atmosphere, furthering 
strengthening the hypothesis that large scale volcanics were active. This negative shift is present in both of the Llandovery sections analyzed in this study (Nevada and Estonia), as well as in the Canadian Arctic section studied by Melchin and Holmden, 2006, and in each case precedes the Ireviken excursion, indicating this is a global excursion. 


\section{BIBLIOGRAPHY}

Azmy, K., Bassett, M. G., Copper, P., and Veizer, J., 1998, Oxygen and carbon isotopic composition of Silurian brachiopods; implications for coeval seawater and glaciations. Geological Society of America Bulletin, v. 110 , no. 11, p. 1499-1512.

Azmy, K., Veizer, J., Wenzel, B., Bassett, M. G., and Copper, P., 1999, Silurian strontium isotope stratigraphy, Geological Society of America Bulletin, v. 111 , no. 4, p. $475-483$.

Bergstrom et al., 1992, Silurian K-bentonites in the Iapetus Region: A preliminary event-stratigraphic and tectonomagmatic assessment. GFF, v. 114, pt. 3, p. 327-334.

Bergstrom, S. M., Huff, W. D., Kolata, D. R., and Melchin, M. J., 1997, Occurrence and significance of Silurian K-bentonite beds at Arisaig, Nova Scotia, eastern Canada. Canadian Journal of Earth Sciences, v.34, p. $1630-1643$.

Bergstrom et al., 1998, The Lower Silurian Osmundsberg K-bentonite. Part I: stratigraphic position, distribution, and palaeogeographic significance. Geological Magazine, v. 135 (1), p. 1-13.

Berner, R. A., 2006, Inclusion of the Weathering of Volcanic Rocks in the GEOCARBSULF Model. American Journal of Science, v. 306, p. 295302.

Bevier, M. L., and Whalen, J. B., 1990, Tectonic significance of Silurian magmatism in the Canadian Appalachians. Geology, vol. 18, no. 5. p. 411-414.

Brand, U., Azmy, K., and Veizer, J., 2006, Evaluation of the Salinic I tectonic, Cancaniri glacial and Ireviken biotic events: Biochemostratigraphy of the Lower Silurian succession in the Niagara Gorge area, Canada and U.S.A. Palaeogeography, Palaeoclimatology, Palaoecology, v. 241, p. 192-213. 
Caputo, M. V., 1998, Ordovician-Silurian glaciations and global sea-level changes. In Landing, E., ed., New York State Museum Bulletin v. 491, p. $15-25$.

Cawood, P. A., van Gool, J. A. M., and Dunning, G. R., 1995, Collisional tectonics along the Laurentian margin of the Newfoundland Appalachians, in Hibbard, J. P., van Staal, C. R., Cawood, P. A., eds., Current Perspectives in the Appalachian-Caledonian Orogen. Geological Association of Canada Special Paper 41, p. 283-301.

Dahlqvist et al., 2005, The lowermost Silurian of Jamtland, central Sweden: conodont biostratigraphy, correlation and biofacies: Transactions of the Royal Society of Edinburgh: Earth Sciences, v. 96, p. 1-19.

Ettensohn, F. and Brett, C.E., 1998, Tectonic components in third order Silurian cycles: Examples from the Appalachian Basin and global implications. In Landing, E., ed., New York State Museum Bulletin v. 491, p. 143-162.

Ettensohn, F. R., and Brett, C. E., 2002, Stratigraphic evidence from the Appalachian Basin for continuation of the Taconian Orogeny into Early Silurian time. Physics and Chemistry of the Earth, v. 27, p. 279-288.

Farrell, J. W., Steven, C. C., and Gromet, L. P., 1995, Improved chronostratigraphic reference curve of late Neogene seawater ${ }^{87} \mathrm{Sr} /{ }^{86} \mathrm{Sr}$. Geology, v. 23, p. 403-406.

Foland, K. A., and Allen, J. C., 1991, Magma sources for Mesozoic anorogenic granites of the White Mountain magma series, New England, USA. Contributions to Mineralogy and Petrography, v. 109, issue 2, p. 195-211.

Gee, D. G., 1975, A tectonic model for the central part of the Scandinavian Caledonides. American Journal of Science, v. 275a, p. 532-568.

Halverson, G. P., Dudas, F. O., Maloof, A. C., and Bowring, S. A., 2007, Evolution of the ${ }^{87} \mathrm{Sr} /{ }^{86} \mathrm{Sr}$ composition of Neoproterozoic seawater. Palaeogeography, Palaeoclimatology, Palaeoecology. v. 256, p. 103-129.

Harris, M. T., and Sheehan, P. M., 1996, Upper Ordovician-Lower Silurian depositional sequences determined from middle shelf sections, Barn Hills and Lakeside Mountains, eastern Great Basin, in Witzke, B. J., Ludvigson, G. A., and Day, J. eds., Paleozoic Sequence Stratigraphy: Views from the North American Craton: Boulder, Colorodo. Geological Society of America Special Paper 306, p. 161-176. 
Harris, M. T., and Sheehan, P. M., 1997, Carbonate Sequences and Fossil Communities from the Upper Ordovician - Lower Silurian of the Eastern Great Basin: in Link, P., and Kowallis, B. J., eds., Proterozoic to Recent stratigraphy, tectonics, and volcanology, Utah, Nevada, southern Idaho and central Montana. Brigham Young University Geology Studies, v. 42, pt. I, p. 105-128.

Harris, M. T., and Sheehan, P. M., 1998, Early Silurian Stratigraphic Sequences of the Eastern Great Basin (Utah and Nevada). In Landing, E., ed. New York State Museum Bulletin, v. 491, p. 51-61.

Heath, R. J., Brenchley, P. J., and Marshall, J. D., 1998, Early Silurian carbon and oxygen stable-isotope stratigraphy of Estonia; implications from climate change. In Landing, E., ed. New York State Museum Bulletin, v. 491, p. 51-61.

Hodell, D. A., Mead, G. A., and Mueller, P. A., 1990, Variation in the strontium isotopic composition of seawater ( 8 Ma to present): Implications for the chemical weathering rates and dissolved fluxes to the oceans. Chemical Geology, v. 80, p. 291-307.

Huff, W. D., Bergstrom, S. M., Kolata, D. R., and Heping, S., 1998, The Lower Silurian Osmundsberg K-bentonite. Part II: mineralogy, geochemistry, chemostratigraphy, and tectonomagmatic significance. Geological Magazine, v. 135, p. 15-26.

Joachimski, M. M., Pancost, R. D., Freeman, K. H., Ostertag-Henning, C., and Buggisch, W., 2002, Carbon isotope geochemistry of the FrasnianFamennian transition. Palaeogeography, Palaeoclimatology, Palaeoecology. v. 181, p. 91-109.

Johnson, M. E., Jia-Yu, R., and Xue-Chang, Y., 1985, Intercontinental correlation by sea-level events in the Early Silurian of North America and China (Yangtze Platform). Geological Society of America Bulletin, v. 96, p. 1384-1397.

Johnson, M. E., Baarli, B. G., Nestor, H., Rubel, M., and Worsley, D., 1991, Eustatic sea-level patterns from the Lower Silurian (Llandovery Series) of southern Norway and Estonia. Geological Society of American Bulletin, v. 103, p. 315-335. 
Johnson, M. E., 1996, Stable cratonic sequences and a standard for Silurian Eustacy, in Witzke, B. J., Ludvigson, G. A., and Day, J. E., eds., Paleozoic sequence stratigraphy: North American perspectives-Views from the North American craton: Geological Society of America Special Publication 306, p. 203-211.

Kaljo, D., and Martma, T., 2000, Carbon isotopic composition of Llandovery rocks (east Baltic Silurian) with environmental interpretation. Proceedings of the Estonian Academy of Sciences, v. 49, no. 4, p. 267283.

Kaljo, D., Martma, T, Mannik, P, Viira, V., 2003, Implications of Gondwana glaciations in the Baltic late Ordovician and Silurian and a carbon isotopic test of environmental cyclicity. Bulletin of Geological Society of France, v. 174 , no. 1 , p. 59-66.

Kiipli, E., Kiipli, T., and Kallaste, T., 2004, Bioproductivity rise in the East Baltic epicontinental sea in the Aeronian (Early Silurian). Palaeogeography, Palaeoclimatology, Palaeoecology, v. 205, p. 255-272.

Kiipli, E., Kiipli, T., and Kallaste, T., 2006, Identification of the O-bentonite in the deep shelf sections with implication on stratigraphy and lithofacies, East Baltic Silurian. GFF, v. 128, p. 255-260.

Koren, T. N., Lenz, A. C., Loydell, D. K., Melchin, M. J., Storch, P. and Teller, L., 1996, Generalized graptolite zonal sequence defining Silurian time intervals for global paleogeographic studies. Lethia, v. 29, 59-60.

Krug, A. Z., and Patzkowsky, M. E., 2004, Rapid recovery from the Late Ordovician mass extinction. Proceedings of the National Academy of Sciences of the USA, v. 101, no. 5, p. 17605-17610.

Kump, L. R., Arthur, M. A., Patzkowsky, M. E., Gibbs, M. T., Pinkus, D. S., and Sheehan, P. M., 1999a, A weathering hypothesis for glaciation at high atmospheric pCO2 during the late Ordovician. Palaeogeography, Palaeoclimatology, Palaeoecology, v. 152, p. 173-187.

Kump, L. R. and Arthur, M. A., 1999b, Interpreting carbon-isotope excursions: carbonates and organic matter. Chemical Geology, v. 161, p. 181-198.

Lehnert, O., Bergstrom, S. M., Benedetto, J. L., and Vaccari, N. E., 1999, First record of Lower Silurian conodonts from South America: biostratigraphic and palaeobiogeographic implications of Llandovery conodonts in the Precordillera of Argentina. Geological Magazine, v. 136 (2), p. 119-131. 
Loydell, D. K., 1998, Early Silurian sea-level changes. Geological Magazine, v. 135, p. 447-471.

Loydell, D. K., Mannik, P., and Nestor, V., 2003, Integrated biostratigraphy of the lower Silurian of the Aizpute-41 core, Latvia. Geological Magazine, v. 140 (2), p. 205-229.

Lyons, W.B., Carey, A.E., Hicks, D.M., and Nezat, C.A., 2005, Chemical weathering in high-sediment yielding watersheds, New Zealand: Journal of Geophysical Research, v. 110, p. 1-11.

Melchin M. J. and Holmden C., 2006, Carbon isotope chemostratigraphy of the Llandovery in Arctic Canada: implications for global correlation and sea level change. GFF, v. 128, p. 173-180.

Montanez, I. P., Banner, J. L., Osleger, D. A., Borg, L. E., and Bosserman, P. J., 1996, Integrated $\mathrm{Sr}$ isotope variations and seal-level history of Middle to Upper Cambrian platform carbonates: Implications for the evolution of Cambrian seawater ${ }^{87} \mathrm{Sr}^{86} \mathrm{Sr}$. Geology, v. 24, no. 10, p. 917-920.

Nestor, V., 1994, Early Silurian chitinozoans of Estonia and North Latvia (Academia 4). Tallinn: Estonian Academy Publishers, 163 pp.

Palmer, M. R., and Elderfield, H., 1985, Sr isotope composition of seawater over the past 75 Myr. Nature, v. 314, p. 526-528.

Payne, J. L., and Kump, L. R., 2007, Evidence for recurrent Early Triassic massive volcanism from quantitative interpretation of carbon isotope fluctuations. Earth and Planetary Science Letters, v. 256, p. 264-277.

Qing, H., Barnes, C. R., Buhl, D., and Veizer, J., 1998, The strontium isotopic composition of Ordovician and Silurian brachiopods and conodonts: Relationships to geological events and implications for coeval seawater. Geochimica et Cosmochimica Acta, v. 62, no. 10, p. 1721-1733.

Raymo, M. E., Ruddiman, W. F., and Froelich, P. N., 1988, Influence of late Cenozoic mountain building on ocean geochemical cycles. Geology, v. 16, p. 649-653.

Richter, F. M., Rowley, B. D., and DePaolo, D. J., 1992, Sr isotope evolution of seawater: The role of tectonics. Earth and Planetary Science Letters, v. 109, p.11-23. 
Ruppel, S. C., James, E. W., Barrick, J. E., Nowian, G., and Uyeno, T. T., 1996, High-resolution ${ }^{87} \mathrm{Sr} /{ }^{86} \mathrm{Sr}$ chemostratigraphy of the Silurian: Implications for event correlation and strontium flux. Geology, v. 24, p. 831-834.

Saltzman, M. R., 2003, Organic carbon burial and phosphogenesis in the Antler Foreland Basin: An out-of phase relationship during the Lower Mississippian. Journal of Sedimentary Research, v. 73, no. 6, p. 844-855.

Saltzman, M. R., and Young, S. A., 2005, Long-lived glaciation in the Late Ordovician? Isotopic and sequence-stratigraphic evidence from western Laurentia. Geology, v. 33, no. 2, p. 109-122.

Sheehan, P. M., 1980, Paleogeography and marine communities of the Silurian carbonate shelf in Utah and Nevada, in Fouch, T. D., and Magatham, E. R., eds., Paleozoic Paleogeography of the West-Central United States Paleogeography Symposium 1: Rocky Mountain Section of the Society of Economic Paleontologists and Mineralogists, p. 19-37.

Shields, G. A., Carden, G. A. F., Veizer, J., Meidla, T., Rong, J., and Li, R., 2003, $\mathrm{Sr}, \mathrm{C}$, and $\mathrm{O}$ isotope geochemistry of Ordovician brachiopods: A major isotopic event around the Middle-Late Ordovician transition. Geochimica et Cosmochimica Acta, v. 67, no. 11, p. 2005-2025.

Torsvik, T. H., Smethurst, M. A., Meert, J. G., Van der Voo, R., McKerrow, W. S., Brasier, M. D., Sturt, B. A., and Walderhaug, H. J., 1996, Continental break-up and collision in the Neoproterozoic and Paleozoic-a tale of Baltica and Laurentia. Earth Science Review, v. 40, p. 229-258.

Veizer et al., $1999,{ }^{87} \mathrm{Sr} /{ }^{86} \mathrm{Sr}, \delta^{13} \mathrm{C}$, and $\delta^{18} \mathrm{O}$ evolution of Phanerozoic seawater. Chemical Geology, v. 161, p. 59-88.

Zhang et al., 2002, A new Llandovery (early Silurian) conodont biozonation and conodonts from the Becscie, Merrimack, and Gun River formations, Anticosti Island, Quebec: Supplement to Journal of Paleontology, v. 76, p. $1-46$ 
APPENDIX A

DATA TABLES 


\begin{tabular}{|c|c|c|c|c|c|c|c|}
\hline Meters & ${ }^{87} \mathrm{Sr} /{ }^{86} \mathrm{Sr}$ & Sr error & Sr ppm & $\delta^{13}$ Ccarb & $\delta^{13} \operatorname{Corg}$ & $\delta^{18} \mathrm{O}$ & Formation \\
\hline 260.0 & & & & 1.793 & & -3.726 & Riga \\
\hline 265.0 & & & & 3.659 & & -3.667 & Riga \\
\hline 269.2 & & & & 3.370 & & -3.311 & Riga \\
\hline 275.0 & & & & 3.413 & & -3.606 & Riga \\
\hline 280.4 & & & & 3.588 & & -3.795 & Riga \\
\hline 286.5 & & & & 3.414 & -26.69 & -4.234 & Riga \\
\hline 288.5 & & & & 3.114 & -26.67 & -4.104 & Riga \\
\hline 289.2 & 0.708441 & 0.000014 & 136.7 & 3.236 & -26.40 & -4.146 & Velise \\
\hline 294.3 & & & & 1.794 & & -5.212 & Velise \\
\hline 296.0 & 0.708423 & 0.000009 & 138.3 & 2.474 & -26.80 & -4.746 & Velise \\
\hline 300.8 & 0.708359 & 0.000008 & 148.9 & 2.241 & -26.49 & -5.437 & Velise \\
\hline 305.2 & 0.708334 & 0.000011 & 143.0 & 1.500 & -27.73 & -5.265 & Rumba \\
\hline 308.1 & 0.708201 & 0.000008 & 227.2 & 0.386 & -27.84 & -4.988 & Rumba \\
\hline 310.1 & & & & 0.169 & & -4.724 & Rumba \\
\hline 310.5 & & & & & & & Rumba \\
\hline 312.1 & 0.708217 & 0.000011 & 236.1 & -0.028 & -28.72 & -5.038 & Rumba \\
\hline 313.2 & & & & -0.509 & & -5.621 & Rumba \\
\hline 316.6 & 0.708184 & 0.000011 & 318.1 & 0.277 & -30.02 & -3.725 & Rumba \\
\hline 318.4 & & & & 0.005 & & -4.563 & Rumba \\
\hline 320.0 & & & & -0.946 & & -4.960 & Rumba \\
\hline 320.3 & 0.708140 & 0.000010 & 242.7 & & -29.50 & & Rumba \\
\hline 322.0 & & & & 0.335 & & -5.021 & Rumba \\
\hline 322.4 & & & & & & & $\begin{array}{c}\text { Saarde } \\
\text { (Staicele } \\
\text { Mem) }\end{array}$ \\
\hline 323.1 & 0.708160 & 0.000008 & 247.1 & & -28.59 & & $\begin{array}{c}\text { Saarde } \\
\text { (Staicele } \\
\text { Mem) }\end{array}$ \\
\hline 323.5 & & & & 0.960 & & -4.841 & $\begin{array}{c}\text { Saarde } \\
\text { (Staicele } \\
\text { Mem) }\end{array}$ \\
\hline
\end{tabular}

Continued

Table 1: Stable isotope data from Ikla Core. Uncertainites are two-sigma mean internal reproducibilities, typically based upon 100 measured ratios. The ${ }^{87} \mathrm{Sr} /{ }^{86} \mathrm{Sr}$ ratios given are normalized for instrumental fractionation using a normal ratio for ${ }^{86} \mathrm{Sr} r{ }^{88} \mathrm{Sr}$ of 0.119400 . The Laboratory reference value for the SRM 987 standard is $\left({ }^{87} \mathrm{Sr} /{ }^{86} \mathrm{Sr}\right)=0.710242 \pm 0.000010$ (one one-sigma external reproducibility). No modifications to the measured normalized ${ }^{87} \mathrm{Sr} /{ }^{86} \mathrm{Sr}$ ratios have been made. 
Table 1 continued

\begin{tabular}{|c|c|c|c|c|c|c|c|}
\hline 324.5 & & & & 1.506 & & -4.967 & $\begin{array}{c}\text { Saarde } \\
\text { (Staicele } \\
\text { Mem) }\end{array}$ \\
\hline 327.5 & & & & 2.119 & -29.14 & -5.065 & $\begin{array}{c}\text { Saarde } \\
\text { (Staicele } \\
\text { Mem) }\end{array}$ \\
\hline 330.9 & & & & 1.911 & & -5.061 & $\begin{array}{c}\text { Saarde } \\
\text { (Staicele } \\
\text { Mem) }\end{array}$ \\
\hline 332.5 & & & & & & & $\begin{array}{c}\text { Saarde } \\
\text { (Staicele } \\
\text { Mem) }\end{array}$ \\
\hline 334.8 & 0.708067 & 0.000009 & 832.1 & 2.423 & -28.79 & -5.035 & $\begin{array}{c}\text { Saarde } \\
\text { (Staicele } \\
\text { Mem) }\end{array}$ \\
\hline 337.5 & & & & & & & $\begin{array}{c}\text { Saarde } \\
\text { (Staicele } \\
\text { Mem) }\end{array}$ \\
\hline 338.0 & & & & 2.562 & & -5.084 & $\begin{array}{c}\text { Saarde } \\
\text { (Staicele } \\
\text { Mem) }\end{array}$ \\
\hline 340.1 & 0.708075 & 0.000009 & 1098.0 & 1.927 & -27.56 & -4.636 & $\begin{array}{c}\text { Saarde } \\
\text { (Staicele } \\
\text { Mem) }\end{array}$ \\
\hline 342.7 & & & & 2.116 & & -5.226 & $\begin{array}{c}\text { Saarde } \\
\text { (Staicele } \\
\text { Mem) }\end{array}$ \\
\hline 343.1 & & & & & & & $\begin{array}{c}\text { Saarde } \\
\text { (Staicele } \\
\text { Mem) }\end{array}$ \\
\hline 344.9 & 0.708090 & 0.000011 & 887.1 & 2.075 & -29.25 & -4.989 & $\begin{array}{c}\text { Saarde } \\
\text { (Staicele } \\
\text { Mem) }\end{array}$ \\
\hline 347.3 & & & & 2.395 & & -4.976 & $\begin{array}{c}\text { Saarde } \\
\text { (Staicele } \\
\text { Mem) }\end{array}$ \\
\hline 350.0 & & & & 2.416 & & -5.152 & $\begin{array}{c}\text { Saarde } \\
\text { (Staicele } \\
\text { Mem) }\end{array}$ \\
\hline 352.5 & & & & 2.428 & & -5.000 & $\begin{array}{c}\text { Saarde } \\
\text { (Staicele } \\
\text { Mem) }\end{array}$ \\
\hline 353.0 & 0.708090 & 0.000008 & 917.8 & & -28.01 & & $\begin{array}{c}\text { Saarde } \\
\text { (Staicele } \\
\text { Mem) }\end{array}$ \\
\hline 354.5 & 0.708093 & 0.000008 & 341.9 & 2.376 & -28.97 & -5.050 & $\begin{array}{c}\text { Saarde } \\
\text { (Staicele } \\
\text { Mem) }\end{array}$ \\
\hline
\end{tabular}

Continued 
Table 1 continued

\begin{tabular}{|c|c|c|c|c|c|c|c|}
\hline 356.6 & & & & & & & $\begin{array}{c}\text { Saarde } \\
\text { (Staicele } \\
\text { Mem) }\end{array}$ \\
\hline 357.0 & & & & 2.586 & & -3.912 & $\begin{array}{c}\text { Saarde } \\
\text { (Staicele } \\
\text { Mem) } \\
\end{array}$ \\
\hline 357.9 & & & & & & & $\begin{array}{c}\text { Saarde } \\
\text { (Staicele } \\
\text { Mem) }\end{array}$ \\
\hline 358.7 & & & & 2.091 & & -4.958 & $\begin{array}{c}\text { Saarde } \\
\text { (Staicele } \\
\text { Mem) } \\
\end{array}$ \\
\hline 361.5 & & & & 2.338 & & -4.938 & $\begin{array}{c}\text { Saarde } \\
\text { (Staicele } \\
\text { Mem) }\end{array}$ \\
\hline 362.2 & & & & & & & $\begin{array}{c}\text { Saarde } \\
\text { (Staicele } \\
\text { Mem) }\end{array}$ \\
\hline 363.8 & 0.708127 & 0.000008 & 423.1 & 1.562 & -27.56 & -4.025 & $\begin{array}{c}\text { Saarde } \\
\text { (Staicele } \\
\text { Mem) }\end{array}$ \\
\hline 369.0 & & & & 1.348 & & -4.246 & $\begin{array}{c}\text { Saarde } \\
\text { (Lemme Mem) }\end{array}$ \\
\hline 371.5 & 0.708068 & 0.000013 & 907.6 & 1.276 & -28.57 & -4.260 & $\begin{array}{c}\text { Saarde } \\
\text { (Lemme Mem) }\end{array}$ \\
\hline 373.4 & & & & 1.684 & & -5.703 & $\begin{array}{c}\text { Saarde } \\
\text { (Lemme Mem) }\end{array}$ \\
\hline 376.1 & & & & 1.969 & & -4.475 & $\begin{array}{c}\text { Saarde } \\
\text { (Lemme Mem) }\end{array}$ \\
\hline 379.0 & & & & 1.839 & & -5.175 & $\begin{array}{c}\text { Saarde } \\
\text { (Lemme Mem) }\end{array}$ \\
\hline 381.4 & & & & 2.417 & & -4.335 & $\begin{array}{c}\text { Saarde } \\
\text { (Lemme Mem) } \\
\end{array}$ \\
\hline 382.1 & & & & & & & $\begin{array}{c}\text { Saarde } \\
\text { (Lemme Mem) }\end{array}$ \\
\hline 384.4 & 0.708069 & 0.000009 & 648.0 & 3.189 & -27.45 & -4.260 & $\begin{array}{c}\text { Saarde } \\
\text { (Lemme Mem) }\end{array}$ \\
\hline 386.8 & 0.708108 & 0.000019 & 233.1 & 2.558 & -28.82 & -4.737 & $\begin{array}{c}\text { Saarde } \\
\text { (Lemme Mem) }\end{array}$ \\
\hline 387.9 & & & & & & & $\begin{array}{c}\text { Saarde } \\
\text { (Lemme Mem) }\end{array}$ \\
\hline 391.0 & & & & 2.703 & & -4.494 & $\begin{array}{c}\text { Saarde } \\
\text { (Lemme Mem) }\end{array}$ \\
\hline 393.5 & & & & 2.828 & & -4.246 & $\begin{array}{c}\text { Saarde } \\
\text { (Lemme Mem) }\end{array}$ \\
\hline 394.0 & & & & & & & $\begin{array}{c}\text { Saarde } \\
\text { (Lemme Mem) } \\
\end{array}$ \\
\hline
\end{tabular}

Continued 
Table 1 continued

\begin{tabular}{|c|c|c|c|c|c|c|c|}
\hline 396.0 & 0.708110 & 0.000009 & 206.6 & 2.396 & -28.27 & -4.789 & $\begin{array}{c}\text { Saarde } \\
\text { (Lemme Mem) }\end{array}$ \\
\hline 398.0 & & & & 3.211 & & -3.612 & $\begin{array}{l}\text { Saarde (Ikla } \\
\text { Mem) }\end{array}$ \\
\hline 399.2 & 0.708056 & 0.000007 & 971.6 & 2.105 & -27.38 & -5.608 & $\begin{array}{c}\text { Saarde (Ikla } \\
\text { Mem) }\end{array}$ \\
\hline 402.0 & 0.708078 & 0.000009 & 1108.0 & 2.736 & -28.73 & -3.429 & $\begin{array}{l}\text { Saarde (Ikla } \\
\text { Mem) }\end{array}$ \\
\hline 403.1 & & & & 2.881 & & -4.432 & $\begin{array}{l}\text { Saarde (Ikla } \\
\text { Mem) }\end{array}$ \\
\hline 407.8 & 0.708027 & 0.000009 & 1083.0 & 2.959 & -28.84 & -3.613 & $\begin{array}{c}\text { Saarde (Ikla } \\
\text { Mem) }\end{array}$ \\
\hline 411.6 & & & & 3.161 & & -4.337 & $\begin{array}{l}\text { Saarde (Ikla } \\
\text { Mem) }\end{array}$ \\
\hline 415.3 & & & & 3.119 & & -4.535 & $\begin{array}{l}\text { Saarde (Ikla } \\
\text { Mem) }\end{array}$ \\
\hline 419.7 & 0.708038 & 0.000008 & 1396.0 & 3.196 & -28.22 & -4.624 & $\begin{array}{l}\text { Saarde (Ikla } \\
\text { Mem) }\end{array}$ \\
\hline 421.0 & & & & 3.354 & & -4.397 & $\begin{array}{c}\text { Saarde (Ikla } \\
\text { Mem) }\end{array}$ \\
\hline 421.3 & 0.708044 & 0.000008 & 857.9 & & -27.94 & & $\begin{array}{l}\text { Saarde (Ikla } \\
\text { Mem) }\end{array}$ \\
\hline 422.5 & & & & & & & $\begin{array}{l}\text { Saarde (Ikla } \\
\text { Mem) }\end{array}$ \\
\hline 424.0 & & & & 3.604 & & -4.448 & $\begin{array}{l}\text { Saarde (Ikla } \\
\text { Mem) }\end{array}$ \\
\hline 428.9 & 0.708072 & 0.000012 & 318.2 & 3.676 & -28.46 & -4.525 & $\begin{array}{l}\text { Saarde (Ikla } \\
\text { Mem) }\end{array}$ \\
\hline 434.0 & 0.708043 & 0.000013 & 967.9 & 3.258 & -29.05 & -4.647 & $\begin{array}{l}\text { Saarde (Ikla } \\
\text { Mem) }\end{array}$ \\
\hline 438.0 & & & & 1.731 & & -4.587 & $\begin{array}{l}\text { Saarde (Ikla } \\
\text { Mem) }\end{array}$ \\
\hline 443.0 & & & & 2.496 & -29.41 & -4.351 & $\begin{array}{c}\text { Saarde (Ikla } \\
\text { Mem) }\end{array}$ \\
\hline 447.0 & & & & 1.983 & & -5.077 & $\begin{array}{l}\text { Saarde (Ikla } \\
\text { Mem) }\end{array}$ \\
\hline 451.3 & 0.708046 & 0.000006 & 510.3 & 2.209 & -28.16 & -5.105 & $\begin{array}{l}\text { Saarde (Ikla } \\
\text { Mem) }\end{array}$ \\
\hline 455.0 & & & & 2.356 & & -4.602 & $\begin{array}{l}\text { Saarde (Ikla } \\
\text { Mem) }\end{array}$ \\
\hline 458.3 & 0.708275 & 0.000011 & 69.3 & 1.960 & -29.20 & -4.996 & $\begin{array}{l}\text { Saarde (Ikla } \\
\text { Mem) }\end{array}$ \\
\hline 460.0 & & & & 0.952 & & -4.473 & $\begin{array}{c}\text { Saarde (Kolka } \\
\text { Mem) }\end{array}$ \\
\hline 462.5 & 0.708239 & 0.000009 & 136.8 & 1.975 & -28.82 & -5.083 & $\begin{array}{c}\text { Saarde (Kolka } \\
\text { Mem) }\end{array}$ \\
\hline
\end{tabular}

Continued 
Table 1 continued

\begin{tabular}{|c|c|c|c|c|c|c|c|}
\hline 466.0 & & & & 2.332 & & -3.757 & $\begin{array}{c}\text { Saarde (Kolka } \\
\text { Mem) }\end{array}$ \\
\hline 469.1 & & & & 1.196 & & -4.766 & $\begin{array}{l}\text { Saarde (Kolka } \\
\text { Mem) }\end{array}$ \\
\hline 470.0 & 0.708151 & 0.000009 & 260.3 & 2.117 & -27.64 & -3.905 & $\begin{array}{l}\text { Saarde (Kolka } \\
\text { Mem) }\end{array}$ \\
\hline 471.2 & & & & 1.580 & & -5.286 & $\begin{array}{c}\text { Saarde (Kolka } \\
\text { Mem) }\end{array}$ \\
\hline 473.0 & & & & 2.297 & & -3.937 & $\begin{array}{c}\text { Saarde (Kolka } \\
\text { Mem) }\end{array}$ \\
\hline 475.1 & & & & 0.837 & & -4.681 & $\begin{array}{c}\text { Saarde (Kolka } \\
\text { Mem) }\end{array}$ \\
\hline 477.3 & & & & 2.412 & & -3.702 & $\begin{array}{c}\text { Saarde (Kolka } \\
\text { Mem) }\end{array}$ \\
\hline 480.0 & & & & 1.801 & & -4.007 & $\begin{array}{c}\text { Saarde (Kolka } \\
\text { Mem) }\end{array}$ \\
\hline 481.0 & & & & 2.014 & & -3.682 & $\begin{array}{l}\text { Saarde (Slitere } \\
\text { Mem) }\end{array}$ \\
\hline 482.7 & & & & 2.090 & & -4.060 & $\begin{array}{l}\text { Saarde (Slitere } \\
\text { Mem) }\end{array}$ \\
\hline 484.9 & & & & 1.982 & & -4.077 & $\begin{array}{c}\text { Saarde (Slitere } \\
\text { Mem) }\end{array}$ \\
\hline 487.9 & 0.708105 & 0.000009 & 146.9 & 1.846 & -27.71 & -4.158 & $\begin{array}{c}\text { Saarde (Slitere } \\
\text { Mem) }\end{array}$ \\
\hline 489.7 & & & & 1.799 & & -4.645 & $\begin{array}{c}\text { Saarde (Slitere } \\
\text { Mem) }\end{array}$ \\
\hline 494.0 & & & & 1.388 & & -4.866 & $\begin{array}{c}\text { Saarde (Slitere } \\
\text { Mem) }\end{array}$ \\
\hline 496.0 & & & & 0.347 & & -4.187 & Pusku beds \\
\hline 497.5 & 0.708127 & 0.000007 & 392.2 & 0.112 & -27.40 & -4.767 & Pusku beds \\
\hline 498.0 & & & & -0.890 & & -3.686 & Pusku beds \\
\hline 498.7 & & & & -0.953 & & -3.499 & Pusku beds \\
\hline 500.2 & & & & 1.024 & & -4.661 & Ohne \\
\hline 502.6 & 0.708171 & 0.000008 & 249.0 & 1.358 & -27.81 & -3.808 & Ohne \\
\hline 505.0 & & & & 1.392 & & -3.913 & Ohne \\
\hline 507.7 & 0.708135 & 0.000008 & 104.0 & 0.915 & -27.97 & -4.907 & Ohne \\
\hline 510.5 & & & & 0.759 & & -3.823 & Ohne \\
\hline 513.0 & 0.708341 & 0.000008 & 139.1 & 1.280 & -26.91 & -3.869 & Ohne \\
\hline 515.0 & & & & 1.465 & & -3.684 & Ohne \\
\hline 516.8 & 0.708132 & 0.000012 & 154.7 & 1.368 & -27.21 & -3.478 & Ohne \\
\hline 518.4 & & & & 1.970 & & -4.034 & Ohne \\
\hline 520.0 & & & & 0.956 & & -4.727 & Ohne \\
\hline
\end{tabular}

Continued 
Table 1 continued

\begin{tabular}{|l|l|l|l|l|l|l|l|}
521.6 & & & & 0.572 & & -4.690 & Ohne \\
\hline 522.8 & & & & 0.710 & & -4.232 & Ohne \\
\hline 524.5 & & & & 0.773 & & -4.904 & Ohne \\
\hline 526.0 & & & & 1.511 & & -3.503 & Ohne \\
\hline 527.8 & 0.708464 & 0.000019 & 35.21 & 1.327 & -26.54 & -2.951 & Ohne \\
\hline 527.9 & 0.708020 & 0.000007 & 127.3 & & -27.24 & & Ohne \\
\hline 527.9 & 0.708034 & 0.000011 & 90.56 & & & & Ohne \\
\hline 528.4 & & & & 2.387 & & -4.653 & Saldus \\
\hline 529.1 & 0.707986 & 0.000011 & 174.3 & & & & Saldus \\
\hline 530.0 & & & & 2.520 & & -4.615 & Saldus \\
\hline 531.1 & 0.708193 & 0.000016 & 120.6 & & -26.76 & & Saldus \\
\hline 532.3 & 0.708111 & 0.000008 & 142.0 & 3.003 & -26.60 & -3.259 & Saldus \\
\hline 533.7 & 0.708154 & 0.000009 & 113.2 & 3.219 & -26.39 & -3.285 & Saldus \\
\hline 534.6 & & & & 2.496 & & -3.407 & Saldus \\
\hline
\end{tabular}




\begin{tabular}{|c|l|l|l|l|l|l|l|}
\hline Meters & ${ }^{{ }^{7} \mathbf{S r}}{ }^{\mathbf{8 6}} \mathbf{S r}$ & Sr error & $\begin{array}{c}\text { Sr } \\
\mathbf{p p m}\end{array}$ & $\boldsymbol{\delta}^{\mathbf{1 3}} \mathbf{C} \mathbf{c a r b}$ & $\boldsymbol{\delta}^{\mathbf{1 8}} \mathbf{O}$ & Formation & Member \\
\hline 2.00 & & & & -0.072 & -2.781 & Ely Springs & Flouride \\
\hline 4.25 & & & & 0.223 & -3.223 & Ely Springs & Flouride \\
\hline 6.75 & & & & -0.098 & -3.230 & Ely Springs & Flouride \\
\hline 8.25 & & & & 0.589 & -5.493 & Ely Springs & Flouride \\
\hline 8.35 & & & & 0.808 & -5.571 & Ely Springs & Flouride \\
\hline 8.60 & & & & 0.748 & -4.610 & Ely Springs & Flouride \\
\hline 8.85 & & & & 0.297 & -3.972 & Ely Springs & Flouride \\
\hline 9.10 & & & & 0.938 & -5.676 & Ely Springs & Flouride \\
\hline 9.20 & & & & 0.483 & -3.311 & Ely Springs & Flouride \\
\hline 9.30 & & & & 0.300 & -2.458 & Ely Springs & Flouride \\
\hline 9.55 & & & & 0.415 & -4.543 & Ely Springs & Flouride \\
\hline 9.80 & & & & -0.099 & -4.447 & Ely Springs & Flouride \\
\hline 10.05 & & & & 0.626 & -3.791 & Ely Springs & Flouride \\
\hline 10.30 & & & & 0.597 & -4.181 & Ely Springs & Flouride \\
\hline 10.55 & & & & 0.926 & -5.306 & Ely Springs & Flouride \\
\hline 10.80 & & & & 0.463 & -3.230 & Ely Springs & Flouride \\
\hline 11.05 & & & & 0.780 & -2.902 & Ely Springs & Flouride \\
\hline 11.30 & & & & 0.315 & -3.601 & Ely Springs & Flouride \\
\hline 11.55 & & & & 0.239 & -2.445 & Ely Springs & Flouride \\
\hline 13.05 & & & & 1.758 & -5.929 & Ely Springs & Flouride \\
\hline 15.05 & & & & 0.881 & -1.607 & Ely Springs & Flouride \\
\hline 17.00 & & & & 1.501 & -5.664 & Ely Springs & Flouride \\
\hline 19.00 & & & & 1.252 & -6.421 & Ely Springs & Flouride \\
\hline 23.00 & & & & 2.378 & -4.969 & Ely Springs & Flouride \\
\hline 25.00 & & & & 2.742 & -6.096 & Ely Springs & Flouride \\
\hline 29.00 & & & & 1.529 & -5.655 & Ely Springs & Flouride \\
\hline 32.50 & 0.708611 & 0.000025 & 32.68 & 1.588 & -6.026 & Ely Springs & Flouride \\
\hline 35.00 & & & & 2.272 & -3.307 & Ely Springs & Flouride \\
\hline 37.00 & & & & 0.573 & -4.070 & Ely Springs & Flouride \\
\hline 41.00 & & & & 0.712 & -6.692 & Ely Springs & Flouride \\
\hline & & & & & & Continued \\
\hline
\end{tabular}

Table 2: Stable isotope data from Pancake Range. Uncertainites are two-sigma mean internal reproducibilities, typically based upon 100 measured ratios. The ${ }^{87} \mathrm{Sr} /{ }^{86} \mathrm{Sr}$ ratios given are normalized for instrumental fractionation using a normal ratio for ${ }^{86} \mathrm{Sr}{ }^{88} \mathrm{Sr}$ of 0.119400 . The Laboratory reference value for the SRM 987 standard is $\left({ }^{87} \mathrm{Sr}{ }^{86} \mathrm{Sr}\right)=0.710242 \pm 0.000010$ (one one-sigma external reproducibility). No modifications to the measured normalized ${ }^{87} \mathrm{Sr} /{ }^{86} \mathrm{Sr}$ ratios have been made. 
Table 2 continued

\begin{tabular}{|c|c|c|c|c|c|c|c|}
\hline 41.00 & & & & 1.086 & -6.334 & Laketown & $\begin{array}{l}\text { Tony } \\
\text { Grove }\end{array}$ \\
\hline 43.00 & & & & 1.038 & -6.738 & Laketown & $\begin{array}{l}\text { Tony } \\
\text { Grove }\end{array}$ \\
\hline 47.00 & & & & 0.982 & -7.233 & Laketown & $\begin{array}{l}\text { Tony } \\
\text { Grove }\end{array}$ \\
\hline 51.00 & & & & 0.845 & -6.044 & Laketown & $\begin{array}{l}\text { Tony } \\
\text { Grove }\end{array}$ \\
\hline 57.00 & 0.708619 & 0.000023 & 24.34 & 1.676 & -3.500 & Laketown & $\begin{array}{c}\text { Tony } \\
\text { Grove }\end{array}$ \\
\hline 63.00 & & & & 1.018 & -6.620 & Laketown & $\begin{array}{l}\text { Tony } \\
\text { Grove }\end{array}$ \\
\hline 67.00 & & & & 1.376 & -6.264 & Laketown & $\begin{array}{c}\text { Tony } \\
\text { Grove }\end{array}$ \\
\hline 71.00 & & & & 1.003 & -5.689 & Laketown & $\begin{array}{l}\text { Tony } \\
\text { Grove }\end{array}$ \\
\hline 75.00 & & & & 1.301 & -8.033 & Laketown & $\begin{array}{c}\text { Tony } \\
\text { Grove }\end{array}$ \\
\hline 78.00 & 0.708801 & 0.000083 & 14.23 & 2.226 & -10.573 & Laketown & $\begin{array}{c}\text { Tony } \\
\text { Grove }\end{array}$ \\
\hline 82.00 & & & & 1.887 & -9.569 & Laketown & $\begin{array}{l}\text { Tony } \\
\text { Grove }\end{array}$ \\
\hline 88.00 & & & & 2.587 & -10.817 & Laketown & $\begin{array}{c}\text { Tony } \\
\text { Grove }\end{array}$ \\
\hline 97.00 & 0.708571 & 0.000027 & 20.74 & 2.191 & -9.841 & Laketown & $\begin{array}{l}\text { Tony } \\
\text { Grove }\end{array}$ \\
\hline 100.00 & & & & 0.345 & -5.375 & Laketown & $\begin{array}{l}\text { Tony } \\
\text { Grove }\end{array}$ \\
\hline 106.00 & & & & -0.126 & -2.842 & Laketown & $\begin{array}{l}\text { Tony } \\
\text { Grove }\end{array}$ \\
\hline 115.00 & 0.708482 & 0.000035 & 10.86 & 2.123 & -8.603 & Laketown & $\begin{array}{l}\text { High } \\
\text { Lake }\end{array}$ \\
\hline 118.00 & & & & 1.166 & -8.794 & Laketown & $\begin{array}{l}\text { High } \\
\text { Lake }\end{array}$ \\
\hline 124.00 & & & & 1.965 & -8.895 & Laketown & $\begin{array}{l}\text { High } \\
\text { Lake }\end{array}$ \\
\hline 133.00 & 0.708546 & 0.000034 & 16.35 & 1.732 & -9.255 & Laketown & $\begin{array}{l}\text { High } \\
\text { Lake }\end{array}$ \\
\hline
\end{tabular}

Continued 
Table 2 continued

\begin{tabular}{|c|c|c|c|c|c|c|c|}
\hline 139.00 & & & & 2.179 & -8.803 & Laketown & High Lake \\
\hline 145.00 & 0.708063 & 0.000028 & 15.28 & 0.907 & -6.275 & Laketown & High Lake \\
\hline 151.00 & 0.708489 & 0.000092 & 12.75 & 1.673 & -7.571 & Laketown & High Lake \\
\hline 157.00 & & & & 1.603 & -7.672 & Laketown & High Lake \\
\hline 163.00 & 0.708899 & 0.000019 & 22.46 & 1.672 & -8.606 & Laketown & High Lake \\
\hline 169.00 & 0.708145 & 0.000053 & 11.16 & 0.901 & -5.814 & Laketown & High Lake \\
\hline 175.00 & 0.708070 & 0.000063 & 16.50 & 0.751 & -7.836 & Laketown & High Lake \\
\hline 181.00 & & & & 0.276 & -6.305 & Laketown & High Lake \\
\hline 184.00 & 0.708156 & 0.000055 & 13.47 & 0.277 & -5.859 & Laketown & High Lake \\
\hline 187.00 & & & & 0.074 & -6.245 & Laketown & High Lake \\
\hline 190.00 & 0.708103 & 0.000024 & 22.99 & 1.057 & -6.566 & Laketown & High Lake \\
\hline 193.00 & & & & 0.754 & -6.332 & Laketown & High Lake \\
\hline 196.00 & & & & 0.693 & -7.299 & Laketown & High Lake \\
\hline 199.00 & 0.707994 & 0.000106 & 29.11 & 0.224 & -4.716 & Laketown & High Lake \\
\hline 202.00 & & & & 0.137 & -5.116 & Laketown & High Lake \\
\hline 208.00 & & & & 0.132 & -2.961 & Laketown & High Lake \\
\hline 214.00 & & & & 0.100 & -3.145 & Laketown & High Lake \\
\hline 220.00 & & & & 0.529 & -5.304 & Laketown & High Lake \\
\hline 226.00 & & & & 0.777 & -6.658 & Laketown & High Lake \\
\hline 232.00 & & & & 1.108 & -6.120 & Laketown & High Lake \\
\hline 238.00 & & & & 0.608 & -5.913 & Laketown & High Lake \\
\hline 244.00 & & & & 0.984 & -7.686 & Laketown & High Lake \\
\hline 247.00 & & & & 1.863 & -3.249 & Laketown & Gettel \\
\hline 251.50 & & & & 2.062 & -4.545 & Laketown & Gettel \\
\hline 255.50 & & & & 2.534 & -4.349 & Laketown & Gettel \\
\hline 260.00 & & & & 0.852 & -4.620 & Laketown & Gettel \\
\hline 260.50 & & & & 0.899 & -5.259 & Laketown & High Lake \\
\hline 265.00 & & & & 1.492 & -5.088 & Laketown & High Lake \\
\hline 269.50 & & & & 1.291 & -6.107 & Laketown & High Lake \\
\hline 274.00 & & & & 0.700 & -7.329 & Laketown & High Lake \\
\hline 278.50 & & & & 1.135 & -6.733 & Laketown & High Lake \\
\hline 282.00 & & & & 1.183 & -6.240 & Laketown & High Lake \\
\hline 285.00 & & & & 2.170 & -3.980 & Laketown & \begin{tabular}{|c} 
Jack \\
Valley
\end{tabular} \\
\hline
\end{tabular}

Continued 
Table 2 continued




APPENDIX B

ADDITIONAL FIGURES 
${ }^{87} \mathrm{Srl}^{86} \mathrm{Sr}$ vs. 1/Sr, lkla Core

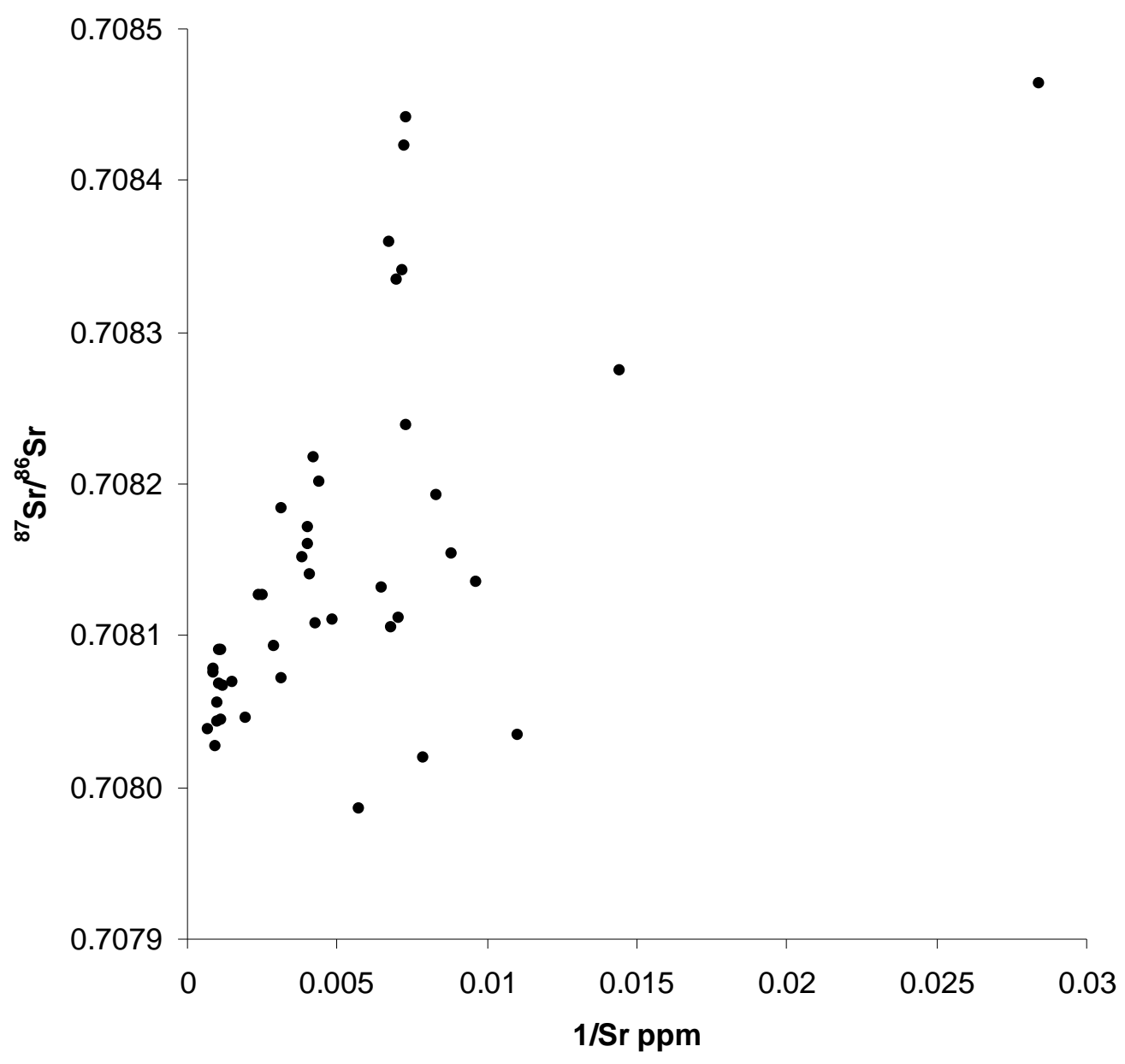

Figure 12: Ikla core ${ }^{87} \mathrm{Sr} /{ }^{86} \mathrm{Sr}$ v. $1 / \mathrm{Sr}$ ppm 
$\delta^{13} C_{\text {org }}$ vs. TOC, Ikla Core

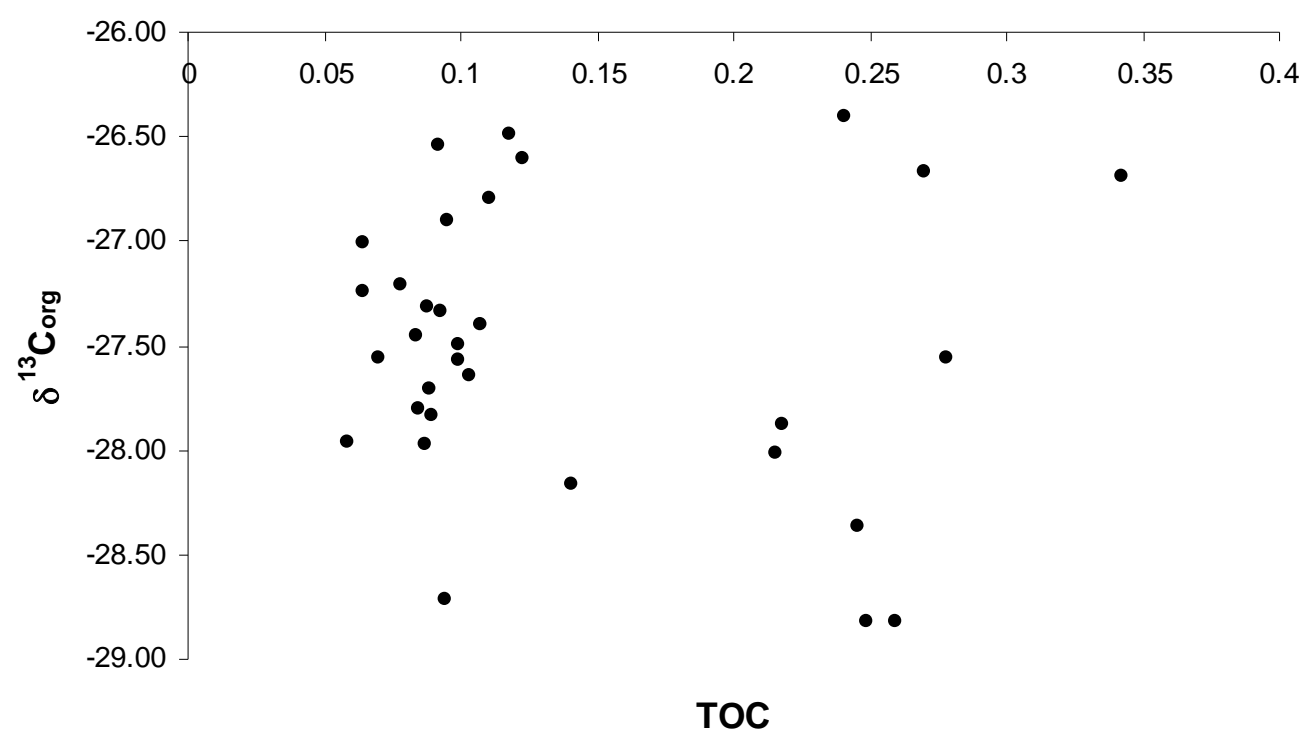

Figure 13: Ikla core $\delta^{13} \mathrm{C}_{\text {org }}$ v. TOC 


\section{${ }^{87} \mathrm{Sr} l^{86} \mathrm{Sr}$ Pancake Range}

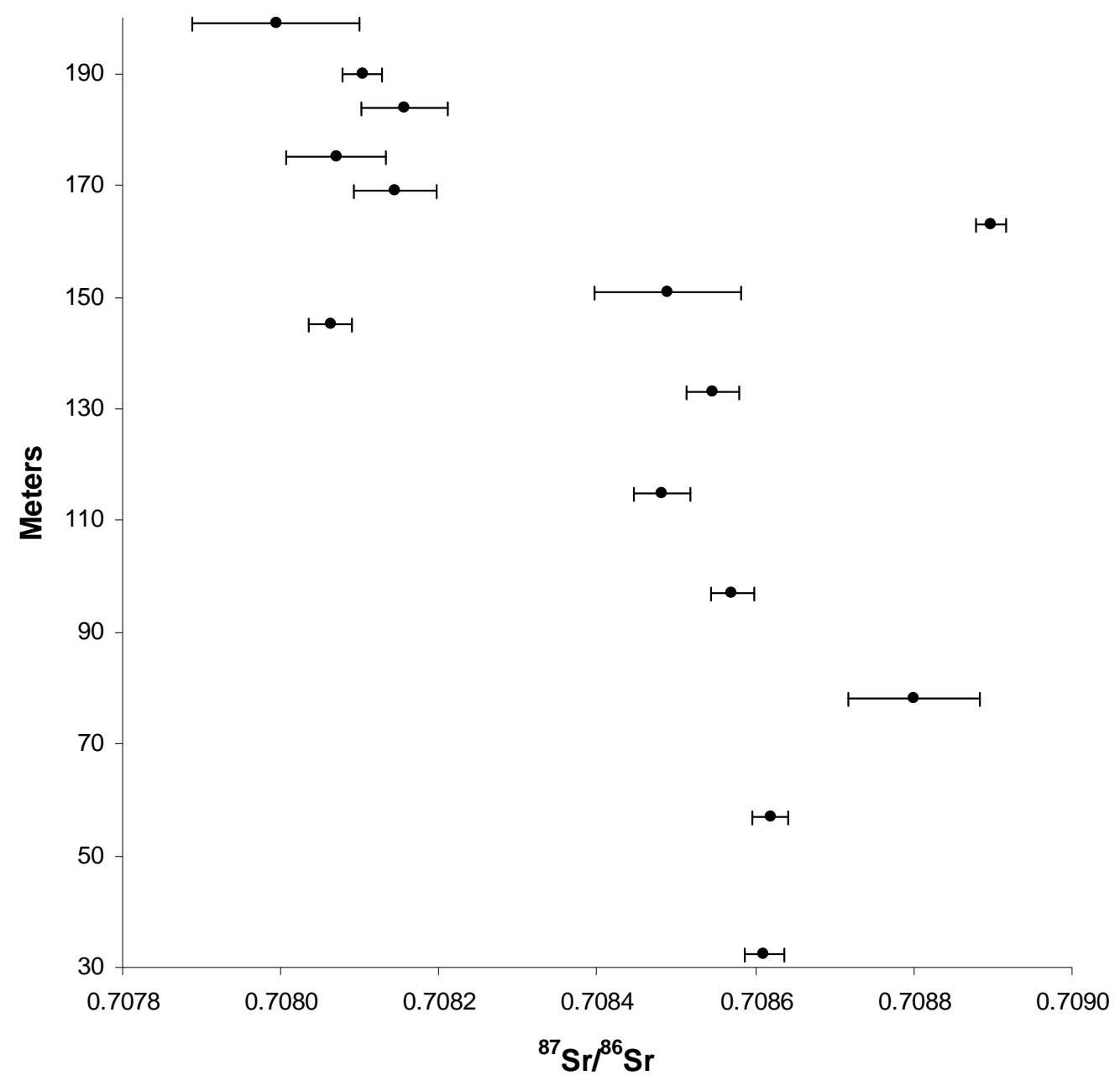

Figure 14: Pancake Range ${ }^{87} \mathrm{Sr}^{186} \mathrm{Sr}$ 
${ }^{87} \mathrm{Sr}{ }^{86} \mathrm{Sr}$ vs. 1/Sr ppm, Pancakes

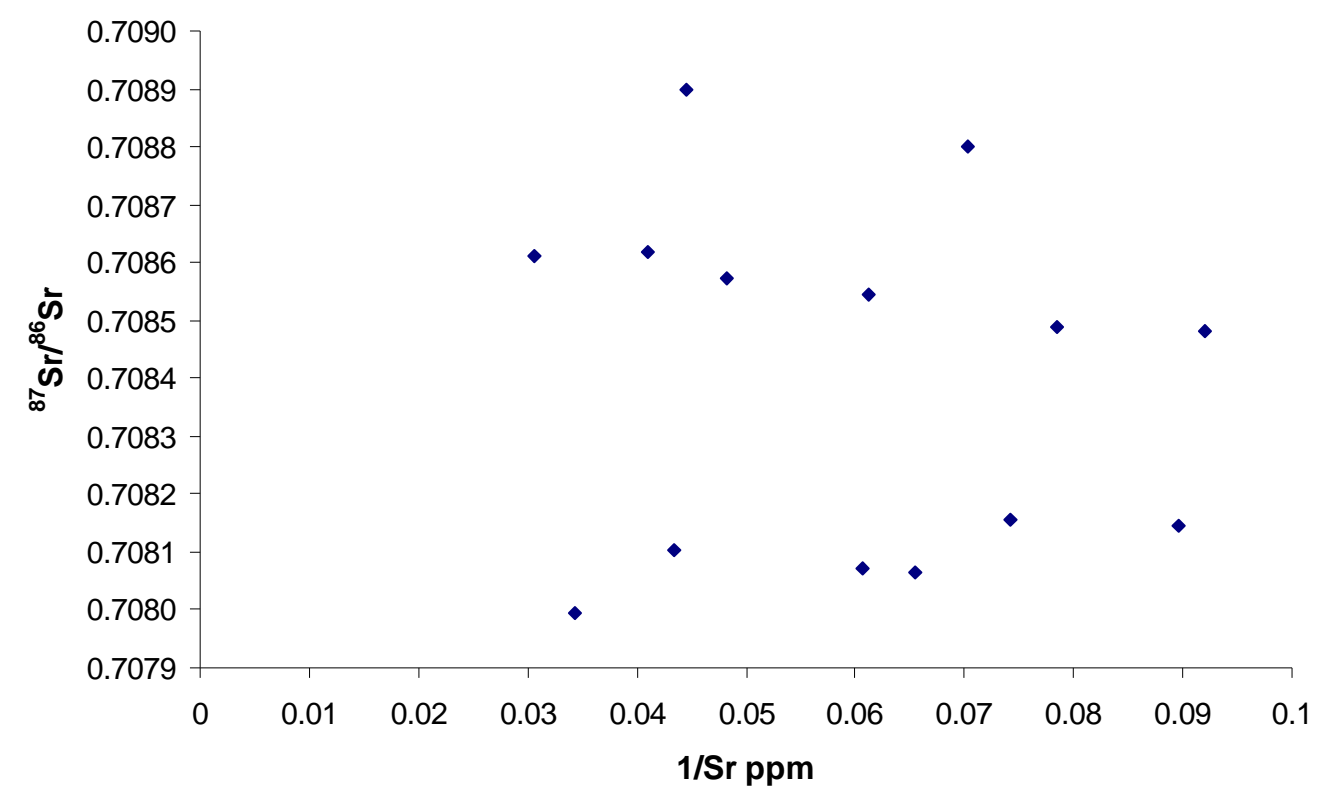

Figure 15: Pancake Range ${ }^{87} \mathrm{Sr} /{ }^{86} \mathrm{Sr}$ v. $1 / \mathrm{Sr}$ 


\section{$\delta^{18} \mathrm{O}$ vs. ${ }^{87} \mathrm{Sr}{ }^{86} \mathrm{Sr}$, Pancake Range}

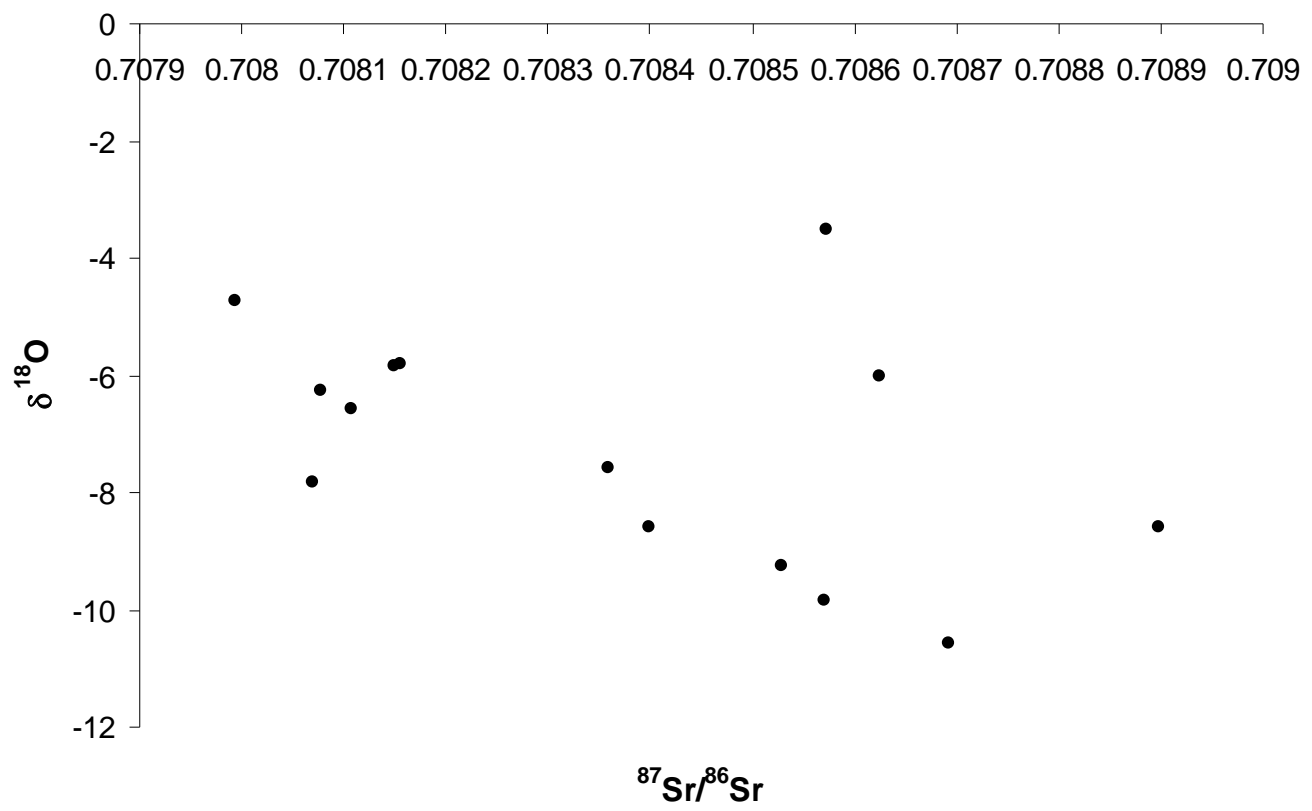

Figure 16: Pancake Range ${ }^{87} \mathrm{Sr} /{ }^{86} \mathrm{Sr}$ v. $\delta^{18} \mathrm{O}$ 


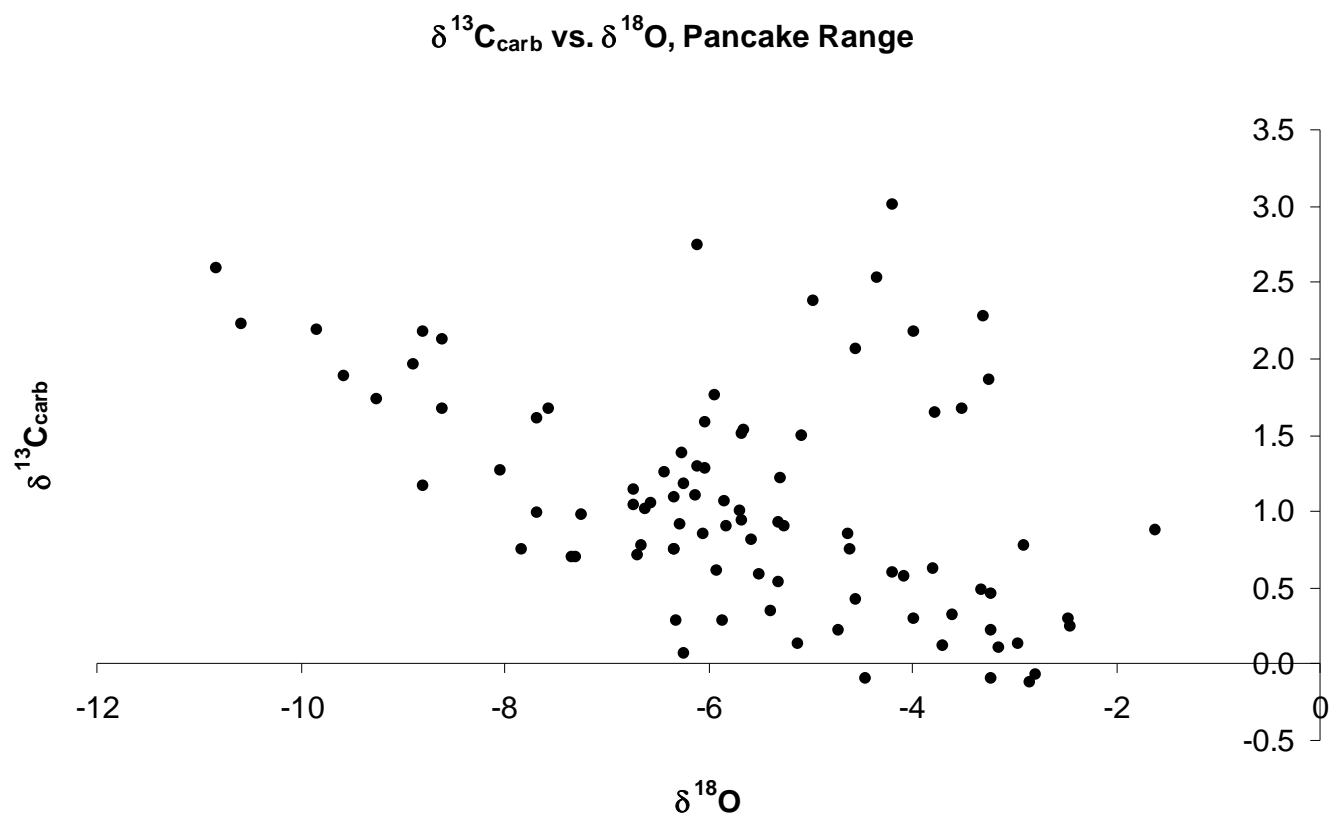

Figure 17: Pancake Range $\delta^{13} \mathrm{C}$ v. $\delta^{18} \mathrm{O}$ 